\title{
Family Demography in sub-saharan Africa: Systematic Review of Family Research
}

\section{Clifford Odimegwu ${ }^{1}$, Nicole De Wet ${ }^{1}$, Sunday Adedini ${ }^{1,2}$, Nompumelelo Nzimande ${ }^{3}$, Sathiyasusuman Appunni ${ }^{4}$, Tessa Hochfeld ${ }^{5}$ \& Tanyaradzwa Dube ${ }^{1}$}

\author{
${ }^{1}$ Demography and Population Studies Programme, Schools of Public Health and Social Sciences \\ University of the Witwatersrand, Johannesburg, South Africa. \\ ${ }^{2}$ Demography and Social Statistics Department, Faculty of Social Sciences, Obafemi Awolowo \\ University, Ile-Ife, Nigeria \\ ${ }^{3}$ Population Studies and Development Studies Department, University of KwaZulu Natal, Durban \\ South Africa.
${ }^{4}$ Statistics and Population Studies Programme, University of the Western Cape,South Africa
${ }^{5}$ Centre for Social Development in Africa, University of Johannesburg, South Africa \\ Clifford.odimegwu@wits.ac.za
}

\begin{abstract}
Background Families in Africa have been undergoing changes recently. The objective of the study was to review published literature on the types, determinants and consequences of family changes in Africa and highlight research gaps in the area.

Methods Sixty-nine journals from 1976 to date that were downloaded from databases such as Pub Med, J Stor, Google Scholar and Science Direct were systematically reviewed.

Results There are family transition in Africa due to socio-economic factors, religious, health and political changes. Seventy-two percent of the studies employed a quantitative approach, $20 \%$ qualitative and $7 \%$ mixed method approach. There are research gaps on topics such as same-sex marriages, cohabitation and father only households.

Conclusion Families in Africa are responding to socio-economic and other changes that are happening around them. Family research is still under studied in Africa. There is need for more mixed method studies that explain the quantitative findings.
\end{abstract}

Keywords: Africa, family transition, systematic review

\section{Introduction}

The traditional family in African societies is an institution that contains a husband with his wives and children, as well as blood or marriage relatives (Okon, 20l3). In the African context, family is based on lineage, kinship and reciprocity (Wusu \& IsiugoAbanihe, 2006). It is the basis of social organizations in Africa which gives primary care to the young and the aged as well as the agent for social control (Takyi 200I). The institution is resilient in sub-Saharan Africa but responding to general socio-economic and political changes (Wusu \& Isiugo-Abanihe, 2006). Furthermore, HIV has played a pivotal role in the recent changes in family in sub-Saharan Africa because of adult mortality of people in their prime age (Dintwat, 20l0).

One could argue that sub-Saharan Africa is going through the second demographic transition which is characterised by increase in divorce, increase in contraceptive effectiveness, change in abortion legislation decrease in marriage and increase in cohabitation. Furthermore, this "second demographic transition" brings a plethora of living arrangements other than marriage, the disconnection between marriage and reproduction, and migration (Lesthaeghe, 2010).

There is a growing body of literature on family transition in Africa; studies have been conducted on a variety of forms of family changes such as family formation, family size, family structure, family dissolution, living arrangements and the effects of family changes. This review argues that family in Africa is in resilience and it is reacting to global changes. This paper seeks to review the documented studies on family changes in Africa.

Research question

What are the types, determinants and consequences of family changes in Africa? 


\section{Method of review}

A systematic approach to all literature was used to identify studies on family change in Africa. This review included academic peer reviewed journals from Pub Med, J Stor, Google Scholar and Science Direct. The key words used for search were "family research", "family dynamics", and "family transitions", "family changes". The following specific words that represent family changes in Africa were also used in the search; "orphanhood", "single motherhood", "divorce", "family formation", "same gendered families", "child headed households", and "nuclear and extend families". The reviewed studies were only limited to African studies. To develop a comprehensive review, journal articles published from 1976 to date were included. Sixty-nine journal articles fitting the inclusion criteria that analysed the determinants of family changes and the consequences of family changes in Africa were reviewed.

\section{Findings}

\section{Family formations}

\section{Changes in family size}

Studies have established that family size in Africa has changed and people are having fewer children in general (Ikamari 2005, Wusu \& Isiugo-Abanihe 2006, Dintwat, 2010, Madhavan \&Schatz 2011, Mturi \& Kembo 20II). Shapiro \& Gebreselassie (2008) analysed fertility behaviour of 24 countries with multiple Demographic and Health Surveys in subSaharan Africa and found that fertility transition had commenced in almost of these countries. The study further highlighted that fertility decline is still ongoing in $65 \%$ of the countries (Shapiro \& Gebreselassie, 2008). Factors such as delayed marriage, female education, female labour force participation, migration, fear of HIV/AIDS as well as the high costs of living lead to reduced fertility and consequently smaller families in sub-Saharan Africa (lkamari 2005, Shapiro \& Gebreselassie 2008, Dintwat 2010, Lachaud et al 2014). Four reviewed studies noted that use of modern contraception has contributed to fertility decline (Heaton \& Hirschl 1999, Shapiro \& Gebreselassie 2008, Dintwat 2010, Mturi \& Kembo 20II). There has been a decline in extended family support leaving child rearing costs as the responsibility of the biological parents so couples now want fewer children (Wusu \& Isiugo-Abanihe 2006). However one study by Heaton \& Hirschl (1999) found that Hausa women in Nigeria still preferred larger families and married early because childbearing confers social status in their culture. This shows how some ethnic groups are less susceptible to changes due to their cultural beliefs.

\section{Premarital child bearing}

Marriage is the context in which child bearing is socially acceptable in most countries (lkamari, 2005). Family formation has changed in Africa in that there is an increase of women who have children out of wedlock (Calves 1999, Wusu \& Isiugo-Abanihe 2006, Mokomane 2006, Palamuleni \& Adebowali 2013). Palamuleni \& Adebowale (2013) studied the levels and patterns of premarital child bearing in subSaharan Africa and the study revealed that premarital child bearing was highest in Namibia (26\%) and lowest in Nigeria (5\%). Furthermore their study revealed that premarital child bearing was higher among women who had no formal education compared to those who were educated. The odds of having a premarital birth significantly decreased with an increase in wealth quintile in Nigeria, Rwanda and Namibia. Women who had early sexual debut had higher odds of having had a premarital birth in Nigeria, Senegal, Congo and Namibia (Palamuleni \& Adebowale, 2013). Premarital child bearing is one of the features of the second demographic transition (Lesthaeghe, 2010). Hence, we argue that subSaharan Africa is undergoing the second demographic transition.

\section{Delayed marriages}

The other noted change in family formation is the issue of increase in age at first marriage in Africa. Marriage has traditionally been universal and early in sub-Saharan Africa but this has changed in most countries. Garennne (2014) studied the levels and trends of age at first marriage for females in 33 subSaharan African countries and found that the average age of first marriage was 18 years for a cohort of women born in 1930 and it increased to 22.6 years for a cohort of women born in 1990. Age at marriage has increased for both males and females. For example, Palamuleni (2010) noted that singulate mean age at marriage (SMAM) for South African males increased from 31.0 years in 1996 to 32.5 years in 2007 and that of females increased from 28 years in 1996 and to 30 years in 2007.

Research has shown that educated women are more likely to delay marriage because of the years they spent in school and their focus of career advancement first (Garenne 2004, Ikamari 2005, Mokomane 2006, Palamuleni 20II). Ikamari (2005) found that risk of first marriage was $24 \%$ lower for the women with primary education and $46 \%$ lower for women with secondary education, all compared with women with no education in Kenya. In addition, delay in marriage has been attributed to increase in bride costs because men will take time to save money for lobola (Dintwat, 2010). Delay in marriage because of education an increase in bride wealth 
show that family formation is resilient but changing responding to socio economic changes such as high cost of living as well as women empowerment in the form of increase in female education. Postponement of marriage is linked to the second demographic transition which proposes that further decline in fertility is caused by delay in marriage (Lesthaeghe, 20I0).

\section{Cohabitation}

Marriage has been traditionally seen as the foundation of family formation and couples had to be married before they started staying together and start child bearing (Calves 1999, Ikamari 2005). There has been a decline in marriages in Africa and there is an increase in alternatives such as consensual cohabiting which is one of the features of the second demographic transition. For example in South Africa, $5 \%$ of African women reported that they were cohabitating 1995 and this had increased to $14 \%$ in 2008 (Posel et al 201 I). A study on cohabitation in sub-Saharan Africa revealed that Southern Africa had the highest proportions of women aged 15-49 years who were cohabiting; with proportion above $10 \%$ in Botswana, South Africa and Namibia (Mokomane, 2006). Seventy percent of the selected countries in East and West Africa had proportions of cohabitants lower than $10 \%$. (Mokomane, 2006).

There are three common interpretations of cohabitation which are cohabitation as an alternative to marriage, a prelude to marriage and an alternative to being single (Mokomane, 2005). Mokomane (2005) revealed that cohabitation in Botswana can be viewed as a prelude to marriage. Posel (20I I) noted a difference in the types of cohabitation between blacks and whites in South Africa. Cohabitation preluded marriage among whites whereas it was an alternative among blacks. Cohabiting has been cited as an alternative to marriage among South African blacks because of the high bride prices men have to pay if they decide to marry (Posel, 20I I).

Furthermore, cohabitation has been attributed to unemployment of men, increase in number of educated women who want to establish careers and premarital child bearing (Mokomane 2006, Dintwat 2010, Moore \& Govender, 2013). One would argue that this is evident of how nuptuality is responding to changes in the economy leading to high unemployment, changes in culture leading to high cost of bride wealth and women empowerment which is focusing on increasing women's level of education.

\section{Changes in family roles}

Four reviewed studies on family roles highlighted that the roles of fathers and mothers in their families are changing (Smit 2002, Montgomery et al 2006, Kimani \&Kombo 2010, Moore 2013). Men were traditionally responsible for economic provision in a household, and women played a domestic role. However, migration of men, unemployment as well as the increasing level of female labour force changed the role of men and women in their families (Smit 2002, Montgomery et al 2006, Kimani \&Kombo 2010). The involvement of women in the labour market has led to the change of a man's role in a family as the sole breadwinner and their involvement in domestic work (Smit 2002, Montgomery et al 2006). Corroborating this finding, Montgomery et al (2006) found that in the context of HIV, men responded by performing roles that went beyond economic support in South Africa. Men were observed engaging in activities such as child care, chores in the house and emotional support.

A study by Kimani \& Kombo (2010) on the challenges faced by nuclear families with absent fathers in Kenya found that women had to fulfil their role as mothers as well as play the role of the father in order to fill in the gap of their missing husbands. Economic provision was traditionally a man's responsibility but these women were left with that responsibility which was very challenging (Kimani \& Kombo, 20I0). As a result, women were now playing a triple role specifically the productive role, reproductive role and fulfilling community expectations. A study by Moore (2013) in South Africa revealed that notions of motherhood have changed from the nurturing role towards increased emphasis on achieving goals such as high educational attainment, employment and financial independence. This shows how women's empowerment through increased in female education and female labour force participation has led to changes in family roles.

\section{Types of families}

\section{Emergence of same gendered families}

One of the non-traditional family forms that have challenged society's notion family is the concept of same-gendered families (Lubbe, 2008). The same-sex marriage legislation and adoption rights for gays and lesbians in South Africa have led to the formation of non-traditional form of families (Rothmann, 20ll). Studies have been conducted to examine parenting and experiences of children from the emerging same gendered families in South Africa (Lubbe 2007, Lubbe 2008, Rothmann 20II). All three of the identified studies employed qualitative research methods and they are South African studies. Lubbe (2007) postulated that parenting and family are constructed hence structural variables, such as the gender composition of families and the division of parental roles, are not as important as process variables such 
as the quality of relationships and the quality of care the children receive. Another qualitative study by Lubbe (2008) on experiences of children from lesbian headed families revealed that the children disclosed that they were from lesbian parent to their friends after being aware that their friends were uneasy, and they did for their friends to accept them (Lubbe, 2008).

\section{Decline in polygamy}

Polygamy which is defined as practice of one man being married to more than one wife at the same time has been a family structure common in many parts of sub-Saharan Africa (Smith-Greenway \& Trinitapoli 2014). Reviewed literature shows that polygamous marriages have declined in many African societies (Meere 1976, Hayase \& Liaw 1997, Heaton \& Hirschl 1999, Mokomane 2006, Fenke 2013). Using Demographic and Health Surveys (DHS) from 34 countries in sub-Saharan Africa, Fenke (20/3) found that about $40 \%$ of women who first married in 1970 were in polygamous marriages whereas about $15 \%$ of women who married in 2005 were in polygamous unions. Reasons for decline in polygamy include delayed marriage, high bride price and high cost of raising children (Heaton \& Hirschl 1999, Wusu \& Isiugo-Abanihe 2006). Furthermore, increase in females attaining education has also played a pivotal role in reducing polygamy (Hayase \& Liaw 1997). Two studies noted that Christianity led to the decline in polygamy in Africa due to its negative moral judgment on polygamy (Hayase \& Liaw 1997, Mokomane 2006).

Single motherhood and female headed households Another aspect of family transformation in Africa is the emergence of single motherhood (Wusu \& IsiugoAbanihe 2006, Dintwat 2010). The two main pathways into single motherhood are giving birth before marriage and experiencing a union dissolution through divorce or widowhood after having at least one dependent child (Wusu \& Isiugo-Abanihe 2006, Clark \& Hamplova 2013). Using survival analysis techniques, Clark \& Hamplova (20/3) found that approximately $50 \%$ of married women will become single mothers as a result of divorce or widowhood in sub-Saharan Africa. Two studies on the relationship between premarital child bearing and marriage found that premarital child bearing results in women being marginalized in the marriage market hence they remain single (Calves 1999, Hattori \& Larsen 2007). Both studies found that women who had a premarital child birth and had been single mothers for four or more years were less likely to get married compared to women who had no children. Two studies noted that the cultural practice of wife inheritance to keep family ties together is declining in Africa hence some widows remain single (Foster 1997, Wusu \& IsiugoAbanihe 2006). The decline of wife inheritance could be attributed to HIV which is encouraging this change in behaviour.

Related to single-motherhood, the phenomenon of female headed households is increasing in subSaharan Africa (Siqwana-Ndulo 1998, Madhavan \& Schatz 2010). For example Siqwana-Ndulo (1998) surveyed 90 households and found that $62 \%$ of them were headed by women. The difference between a single mother and a female household head is that a single mother can be in a male headed household who is not her husband. Moreso, the female head may not be necessarily the single parent for example a grandmother as the head of household. The main causes of the establishment of female headed households are male migration, widowhood, and increase in divorce and pregnancies before marriage (Siqwana-Ndulo 1998, Katapa 2006, Hattorri \& Larsen 2007).

\section{Orphanhood and child headed households}

An orphan is defined as a child below the age of 18 who has lost at least one parent ( $\mathrm{Ha}$ et al, 20I5). All the 5 studies that examined orphanhood noted that HIV/ AIDS epidemic has contributed immensely to the increase in orphanhood in Africa (Foster 1997, Monasch \& Boerma 2004, Hosegood et al 2007, Meintjes et al 20l0, Ha et al 20l5). Ha et al (2015) noted that there are 14.9 million AIDS orphans in sub Saharan Africa. This shows how family is responding to the epidemic. Using Demographic and Surveillance Systems from Malawi, Tanzania and South Africa, Hosegood et al (2007) found that the prevalence of paternal orphanhood is higher than maternal orphanhood because men are older than their wives and the sex differences in HIV infection and survival times (Hosegood et al 2007). In Tanzania, $5 \%$ of children under the age of 18 had lost a mother whereas the figure was $9 \%$ for those who lost a father (Hosegood et al 2007).

Four out of the five studies found that even though there is an increase of orphanhood, there is no evidence that there is a high number of child headed households as a result (Monasch\& Boerma 2004, Hosegood et al 2007, Madhavan \& Schatz 2007, Meintjes et al 2010). A child headed household is defined as a household headed by a person who is less than eighteen years old (Hosegood et al, 2007). Hosegood et al (2007) found no relationship between orphanhood and child headed households in Tanzania, Malawi and South Africa. Buttressing this finding, Meintjes et al (2010) also did not find evidence that child headed households are rapidly growing phenomena in South Africa suggesting that 
kinship networks still provide care for AID orphans. On the contrary Foster et al (1997) found that child headed households are a new way of coping as people respond to the impact of AIDS in families in Zimbabwe. Child headed households were established because of reasons such as extended families' reluctance to take them in, death of relatives, refusal of relatives to move in with children.

\section{Child fostering}

Child fostering which is defined as the custom of children living outside of the natal home is practiced throughout much of sub-Saharan Africa (Monasch \& Boerma 2004, Hosegood 2007, Pillai\& Sharma 2013, Gant \& Yeatman 2014). There are two categories of child fostering which are crisis and non-crisis situation fostering. Crisis situation fostering is a strategy used by families to cope with unexpected and ongoing difficulties. For example, fostering as a result of death of a parent (Monasch \& Boerma 2004, Hosegood 2007), divorce (Gant \& Yeatman 20I4) and migration (Monasch \& Boerma, 2004). On the other hand noncrisis child fostering is a strategy to strengthen kinship ties (Pillai\& Sharma 2013) and also sharing cost of children (Wusu \& Isiugo-Abanihe 2006). Wusu (2006) noted that the practice of non-crisis fostering to spread childrearing cost is declining so childrearing is the responsibility of biological parents only. Grant \& Yeatman (20/2) examined the change in child fostering patterns in 14 sub-Saharan African countries and found that there was a decline in non-orphan fostering and an increase in crisis orphan fostering in countries where there was high HIV prevalence.

\section{Nuclear and extended family}

There are three types of families which are nuclear family, single-parent family and extended family (Dintwat, 2010). The sub-Saharan community has been traditionally dominated by the extended family which comprises of generations of close relatives living together as opposed to a married couple and living with their biological children (Wusu, 2006). Two reviewed studies noted that the concept of family in an African setting has reduced in size to become nuclear which consists of only father, mother and children due to urbanization and modernisation (Amoateng \&Heaton 1989, Kimani \& Kombo 2010). Amoateng \& Heaton (1989) noted that Christianity has eroded the basis of the extended family through its encouragement of individual achievement and the introduction of the nuclear family system. In the same vein Adegoke (2010) noted that the extended family system which used to resolve conflicts between couples is no longer operating effectively like in the past hence the divorce rates are increasing. However a study by Siwqana-Ndulo (1998) found that extended families still exist and black families in rural South Africa are not moving towards the nuclear set up. Buttressing this point, Frantz et al (2015) noted that multi-generational co residence is still a norm and a widely preferred option in South Africa. As mentioned above, extended families are the main care givers of orphans in sub-Saharan Africa (Monasch\& Boerma 2004, Hosegood et al 2007, Madhavan \& Schatz 2007, Meintjes et al 2010). This shows that extended families are still pivotal in most African societies.

\section{Determinants of family changes \\ Women's empowerment}

Women empowerment can be defined as the extension of freedom of choice and action to a woman's life (Duflo, 20/2). It focuses on improving the ability of women to access elements of development such as health, education, economic opportunities and political participation (Duflo, 20I2). Women in Africa are becoming increasingly empowered and this has had an impact on family. Progress in increasing women's educational attainment has been identified as one of the key factors contributing to sustained fertility decline across sub-Saharan Africa (Shapiro \& Gebreselassie, 2008). Two of the proximate determinants of fertility, use of modern contraception and the percentage in union, are influenced by women's educational attainment (Shapiro \& Gebreselassie 2008, Palamuleni \& Adebowali 20I4). Takyi (200 I) \& Adegoke (20I0) noted that women who attained higher levels of education were more likely to divorce in Ghana and Nigeria. Furthermore, delayed marriages have been attributed to increase in women's education attainment and their preference to advancing their career first before getting married (Ikamari, 2005). Mokomane (2006) noted that educated women prefer cohabiting to avoid the cultural subordination of wives to their husbands that is typical of traditional a marriage in many societies in Africa. This evidence supports the argument that family is resilient but changing due to global ideologies such as promoting women empowerment as it is imperative for development (Duflo, 20।2).

\section{Migration and family changes}

Three out of the four reviewed studies on migration noted that despite its improvement in the welfare of people, labour migration of a spouse is associated with marital dissolution and consequently a weakened family structure (Modo 200I, Dintwat 20I0, Anglewicz 20I2). A study in Lesotho found that $10 \%$ of married men who migrated to work in South Africa abandoned their wives and remarried in South Africa (Modo, 200I). Dintwat (2010) noted 
that labour migration of men from Southern African countries such as Botswana, Lesotho, Malawi and Zambia to South Africa resulted in men having "small houses" which are extramarital relationships where they even had children. Most of these men divorced when they went back home.

In South Africa some mothers migrate to urban areas leaving children with their grandmothers (Posel \& Casale 2003, Hosegood et al 2007, Moore 20I3, and Tangwe 2013). Posel \& Casale (2003) noted that some of the women in rural South Africa migrate to look for employment in urban areas leaving their children with grandmothers when their children get older and they have more expenses such as school fees.

\section{Urbanisation and family changes}

Reviewed studies showed that urbanisation has contributed immensely to family change in Africa. For example, urbanisation was associated with fertility decline (Shapiro \& Gebreselassie 2008) delayed marriage (Ikamari 2005), cohabitation (Moore \& Govender 2013) and decline in polygamy (Mere 1976, Hayase \& Liaw 1997). Urbanisation has led to the decline in polygamy in Africa because of high cost of living, shortages of houses, weakened kinship system and high risks of unemployment in the urban areas. A study by Hayase and Liaw (1997) on polygamy in sub-Saharan Africa found that there were lower rates of polygamy in urban areas compared to rural areas in Senegal, Ghana, Kenya and Zimbabwe (Hayase \& Liaw 1997). The study that examined the association between premarital child bearing and place of residence in sub Saharan African yielded inconclusive findings. Premarital childbearing was attributed to residing in urban areas in Nigeria, Senegal, Congo and Namibia but rural women were more likely to have had premarital child bearing in Malawi and Rwanda (Palamuleni \& Adebowali 20I3).

\section{Marital dissolution}

One of the themes on family change in sub Saharan Africa that has been of interest to scholars is divorce. Family is central to African societies hence disruptions in family structure have socioeconomic consequences on the individuals as well as the society at large (Takyi, 200I). A study in Ethiopia found that $45 \%$ of first marriages in Ethiopia end in divorce within 30 years, and $65 \%$ of women who divorce do so within the first five years of marriage (Tilson \& Larsen 2000). All four studies that examined the association between HIV and marriage dissolution established that HIV was associated with marriage dissolution either through divorce or widowhood (Porter et al 2004, Floyd et al 2008, Anglewicz, 2012). A study by Porter et al (2004) in Uganda found an association between HIV being positive and both divorce or separation and widowhood. Discordant HIV positive couples were more likely to divorce or separate whereas concordant couples were more likely to experience widowhood.

Studies have found that childlessness is a determinant of divorce in Africa (Tilson \& Larsen 2000, Takyi 200I, Reniers 2003, Adegoke (20I0). The five studies that examined the role of religion found that religious affiliation was significantly associated with divorce in Ghana and Malawi (Amoateng \& Heaton 1989, Tilson \& Larsen 2000, Reiners 2003, Takyi \& Gyimah 2007, Adegoke 2010). Studies that considered the association between age at marriage and divorce found that women who marry young were significantly more likely to divorce (Amoateng \& Heaton 1989, Tilson \& Larsen 2000, Takyi 200I, Reniers 2003, Takyi \& Gyimah 2007, Adegoke 2010). The three reviewed studies that examined the association between polygyny and divorce found that people in polygamous marriages were more likely to divorce compared to women in monogamous marriages in Ghana and Malawi (Takyi 200I, Reiners 2003, Takyi \& Gyimah 2007). Two studies found that less educated women were less likely to divorce than their educated counterparts in Ghana and Nigeria (Takyi 200I, Adegoke 20l0). Other studies found that women who attained higher education were less likely to divorce compared to women with less education in Ethiopia and Ghana (Amoateng \& Hilton 1989 and Tilson \& Larsen 2000). Contrasting these findings Reiners (2003) found no association between education and divorce in Malawi.

\section{Outcomes of family changes}

Effects of family changes on children's education

The reviewed studies on the impact of family changes on children's education found that parental absence has a negative impact on education (Chuong \& Operario 20I2, Thiombiano et al 2013, Akanle 20l4, $\mathrm{Ha}$ et al 2015). Two of the reviewed studies noted that orphanhood had a negative influence on children's education in South Africa and Zimbabwe (Choung \& Operario 20II, Ha et al 20I5). Choung and Operario (20II) found that orphaned children were more likely to experience delay in education compared to their non-orphaned counterparts in South Africa. Supporting this view, $\mathrm{Ha}$ et al (2015) found that orphanhood significantly affected children's access to education in Zimbabwe. Orphans were significantly less likely to be attending school and they were more likely to be school dropouts compared to non-orphans ( $\mathrm{Ha}$ et al, 20l5).

Moreover, De Wet (20/3) found that parent abseentism was associated with adolescents working for 10 or more hours a week in South Africa. She 
further stipulated that even though it is legal for them to work, the long working hours jeopardise their school completion and these adolescents will be unskilled workers who will struggle to find jobs in the long run. A study by Thiombiano et al (20/3) in Burkina Faso revealed that children who had divorced mothers had a lower probability of entering school compared to children who had married mothers. Furthermore, Akanle (2014) found that having one parent absent had a negative impact of the children's education and also increased chances of children to commit crime in Nigeria.

\section{Family change and child survival}

Reviewed studies showed that family changes have had both negative and positive effects on child survival depending on the type of change. Marital dissolution has been associated with higher likelihood of child mortality for children in Africa (Clark \& Hamplova 2013, Thiombiano 2013). Clark \& Hamplova (2013) found that children who had a previously married mother had a higher risk of dying relative to children who had married parents in nine countries in sub-Saharan Africa. Corroborating this finding, Thiombiano (20/3) found that children of divorced women had higher estimated under-five mortality risks than those living with married mothers in Burkina Faso.

On a positive note, Izugbara (20I4) found that female-headed households were less likely to experience mortality among under- 5 children than male-headed households in Nigeria. With regards to family size, Izugbara (2014) found that households with a higher number of children even born were more likely to experience child mortality compared to households which had I to 4 children only. This shows how changes towards smaller family size increase child survival. Two studies noted that women in monogamous marriages were less likely to experience child mortality relative to women in polygamous marriages (Omariba \& Boyle 2007, Smith-Greenway \& Trinitapoli 20l4).

\section{Family change and risky sexual behaviours}

Parents have been traditionally been viewed as having primary influence on health risk behaviour of young people. Four reviewed studies focused on the association between family structure and sexual behaviour of young people. Findings indicated that family transitions were strongly associated with risky sexual behaviour among young people (Operario et al 20II, Defo \& Dimbuene 2012, Ntaganira et al, 20I2). Defo \& Dimbuene (20I2) found that living within two-parent families all the time, either nuclear or extended was strongly associated with lower rates of sexual debut in Cameroon. On the contrary, students from single parent homes were less likely to have multiple sexual partners in Nigeria (Odimegwu \& Adedini 2013).

With regards to married people, studies have established that family changes lead to promiscuity which can increase HIV rates. As mentioned above, some men who migrate leaving their wives behind engage in extra marital relationships (Modo 200I, Dintwat 2010). In the same vein, some women who stay behind do the same. For example Kimani and Kombo (20l0) found that some married women who had absent husbands had multiple sexual partners in Kenya.

\section{Female headed households and poverty}

Four reviewed studies on female headed households and poverty established that female headed households were poorer compared to male headed households. Katapa (2006) found that female-headed households did not have sufficient food and they did not own assets in Uganda. A study in South Africa found that female headed households had lower incomes, lower rates of employment and lower educational attainment than male headed households (Goebel et al, 20l0). A study in Kenya found that married women, who had absent husbands faced economic challenges (Kimani \& Kombo, 20l0). Murreta \& Derresa (20I4) noted that $35.3 \%$ of the sample female headed households in rural Ethiopia were poor. They further established that educational attainment of the head was one of the key determinants of poverty for female headed households.

\section{Family size and resource allocation}

Reduced family size results in lower household economic dependency ratio and also relieves some of the resource constraints that may force families hence children are allocated with more resources (Lachaud et al, 20l4). Lachaud et al (20l4) examined how patterns of parental investments differ systematically between large and small families in the context of fertility decline in Ouagadougou in Burkina Faso. Results revealed that children from smaller families were more likely to be enrolled in school or attain post-primary school level irrespective of their age and gender compared to children from larger families (Lachaud et al 2014). This shows how children are allocated with more resources if the family size is smaller. Furthermore, Omariba \& Boyle (2007) noted that a decline in polygamy improves child survival because families will be smaller. They further stipulated that the advantage of monogamy is that there will be more financial resources available for healthy childrearing (Omariba \& Boyle, 2007). 


\section{Policies on family}

\section{Policies on family}

Many countries in Africa do not have an explicit family policy and policies regarding families are embedded within their national population policies. The aspect on family which is mentioned in national population policies is that of reduced fertility which will lead to reduced family size. For example the Ugandan Population Policy 2008 highlighted problems with high fertility, early child bearing and adolescent child bearing hence it came up with a strategy to advocate for affordability, availability and accessibility of family planning (Ministry of Finance, Planning and Economic Development, 2008). Similarly, the population policy of Ghana stated that attempts will be made to discourage economic and financial policies that encourage people to have large families (National Population Policy on Ghana, 1994). Furthermore, the national population policy of Ghana (1994) stated that it aimed to increase mean age at marriage from 18 years to 20 years through education. The policy shows how the government wants to delay family formation by as increasing education thus we argue that families in Africa respond to changes that occur around them.

The department of Social Development in South Africa has a white paper on families in South Africa. The white paper views the family as important to development and wants to mainstream family matters into government-wide, policy-making initiatives in order to bring about positive family wellbeing and socio-economic development. The vision of the white paper is to have families that function well, peaceful, safe, stable and economically selfsustaining. Furthermore the vision is to have families that also provide care as well as financial, spiritual, physical, emotional, psychological, and intellectual support for their members (Department of Social Development, 20I2).

\section{Social protection policies and family changes}

In South Africa there is a social protection policy known as the Child Support Grant (CSG) that was initiated in 1997 and pays a small monthly cash amount to poor children under the age of 16 years old through their primary caregivers. Two studies in South Africa found child support grant further discourages father's responsibility to pay maintenance and support children (Patel and Hochfeld 20II, Jordan et al 2014). Patel and Hochfeld found that $30 \%$ of the women indicated that their children's fathers stopped giving them maintenance since they started receiving the grant.

Studies have also studied whether the child support grant in South Africa influences family formation. Makiwane et al's study (2006) found that increase of teenage pregnancy was not related to the introduction of the child support grant. However, a study by Hölscher et al (2009) found that $63 \%$ of participants in the quantitative study saw a direct link between the introduction of the grant and teenage pregnancy. Jordan et al (2014) conducted some interviews and found that some of the young women were encouraged to fall pregnant so that their families could access the child grant.

The social protection policies have helped in alleviating poverty in families in South Africa. For example Patel \& Hochfeld (20II) found that $79 \%$ of the women they studied believed that they could take better care of their children with the child grant (Patel \& Hochfeld, 20I I). The is also an old age grant policy in South Africa whereby people over 60 years old receive a grant which has helped in reducing poverty in their households (Tangwe, 20I3). Tangwe (20I3) noted that some pensioned elderly black South Africans live in intergenerational households and they are the primary caregivers. They act as breadwinners and provide for their unemployed children, orphans, grandchildren and other relatives. The grant benefits all the family members as it contributes to necessities such as buying food, payment of school fees, transport, rent, electricity and water (Tangwe, 20l3).

\section{Responses to change}

Scholars have also studied on how individuals respond to family changes in Africa. For example, Kannae and Pendleton (1994) studied the fertility attitudes of Ghanaian government employees and found that most respondents were against government's interference with the number of children a couple should have and they believed that an educated man should have as many children as possible.

Mokomane (2005) researched on the attitude towards cohabitation among women in Botswana. The main finding was that people viewed cohabitation as a disadvantage. Cohabiting men and women generally cited that marriage was better because it has better legal securities, more stable, socially acceptable and receive more support than cohabitation.

Onuche (2009) studied the perceptions Nigerians had on same-sex marriages. His main finding was that Nigerians consider same sex marriage as an insult to the traditional concept of marriage and it should not be legally recognized. Most Nigerians think a marriage without procreation is incomplete hence they are against legalisation of same sex marriages (Onuche, 2009).

Bojuwoye \& Akpan (2009) researched on the reactions of children to divorce in South Africa and 
found that age when parents divorced, current age, gender and family dynamics such as re-marriage, finance and relationships with custodian and noncustodian parents were important to participant's reactions to their parent's divorce. Most children who had parents who divorced when they were young reported that they had forgotten completely about the divorce. Male respondents viewed their father's absence as not having a role model whereas female respondents saw their father's absence as their mother's deprivation of a helper. With regards to family dynamics, most of the girls did not like the idea of having a step mother (Bojuwoye \& Akpan, 2009).

\section{Methodology}

Seventy-two percent of the reviewed studies employed the quantitative approach, $20 \%$ of studies were qualitative and $7 \%$ employed the mixed method approach. Samples of the reviewed studies were sizeable, only two out of the 50 quantitative studies had less than 100 respondents (Foster 1997, Modo 200 I) the rest had large sample sizes. Seventysix percent of the studies had samples sizes that were over 1000. Regarding data sources, 10 out of the 50 quantitative studies made use of primary data, the other 40 made use of secondary data which was mainly large national surveys. Thirty-four percent of the quantitative studies utilized the Demographic and Health Surveys as the data source. Nine of the qualitative studies collected data using methods such as in depth interviews, ethnographies, narratives and focus group discussions whereas six of them were desktop reviews. Four of the 5 studies which used the mixed method approach combined surveys with in-depth interviews (Siqwana-Ndulo 1998, Mokomane 2005, Ankale et al 2014, Jordan \& Patel 2014). One of the qualitative studies made use of indepth interviews, focus group discussions and surveys as data collection methods (Holscher, 2009). Only five of the studies analysed longitudinal data (Porter 2004, Hosegood et al 2007, Madhavan \& Schatz 2010, Lachaud et al 2014, Grant \& Yeatman 2014) whereas the rest analysed cross sectional data.

Most of the quantitative researchers employed different measures to test the relationships between independent and dependant variables. Only three of those studies employed a simple bivariate measure of association (Oppong 1977, Smit 2002, Goebel 2010) and the majority (84\%) were employing multivariate statistical analysis. Only $6 \%$ of the quantitative studies employed descriptive statistics (Foster 1997, Modo 200I, Monasch \& Boerma 2004, Mokomane 2006, Patel \& Hochfeld 2006). More than half of the dependent variables $(51 \%)$ were demographic. These included family size, marital status, age at marriage and education. Fourteen percent of the studies had outcome variables on family types and relationships. These included orphanhood, child headed households, single motherhood, female headed households, polygamy, same gendered families, parenting practices and copying mechanisms. Four of the studies had health outcomes due to family changes (child mortality) as the dependant variable. Only one study analysed data using a multilevel-model approach (Izugbara, 20|4).

\section{Theory}

Only 19 out of the 69 reviewed studies (28\%) utilized theories. Six of the 19 studies were guided by fertility theories such as Davis/Blake (1956), Caldwell (1982) theory of fertility decline, Bongaarts (1978) proximate determinants of fertility and Easterlin (1975) framework for fertility analysis. Future research on family in Africa could be improved by using theoretical frameworks to guide research design, development of research instruments and interpretation of findings. EspingAndersen \& Billari (2015) proposed a multiple equilibrium framework based on the argument on the importance of the ongoing transformation of gender roles and relations. They posited a return to "more family" as gender egalitarianism gains normative status. The framework helps explain both the past trend of less family and the current reversal. Future studies could utilize this theory in the African context.

\section{Gaps}

After reviewing the studies one of the identified gaps in literature is on research on the same gendered families in Africa. Scientific literature on samegendered families and parenting remains limited in South Africa and Africa at large because homosexuality is illegal in most African countries and is still stigmatised even in South Africa where it is legal. All the reviewed studies on this new type of family were qualitative, quantitative research on such families are needed to test associations with different independent and dependent variables. Furthermore, homosexuality has been studied in the context of HIV IAIDS and has not been given much attention as a family form.

Furthermore, the other identified gap in the reviewed studies is on step families in Africa. Some people remarry after marital dissolution caused by either widowhood or divorce hence blended families are created. Studies in America and Netherlands have shown that children who were staying in original, two-parent households have better wellbeing than children in stepfather households (Amato 1987, Hanson et al 1996, Spruijt \& Goede 1997). 
Hence, it will be worthwhile to conduct research on the dynamics in step families in Africa.

Levels and determinants of cohabitation have been documented in Africa but evidence is sparse on how cohabitation influences the child wellbeing. Furthermore, African studies that examined family change and child health mostly looked at the association between single motherhood or female headed households and child mortality. Schemeer (20II) found that child health outcomes are better for children whose parents marry than those who cohabit in America. Given that levels of cohabitation are increasing in Africa, this could be a research gap that needs to be filled.

Another identified research gap is on father only households in Africa. There are emerging father only households in some parts of Africa for example Zimbabwe, were the women migrate and leave their children with their fathers or widowers who stay with their children. There is need to conduct research on such families in Africa. Furthermore, more research is needed on how individuals and the societies are responding to family changes in Africa.

With regards to methodology, more studies which use the mixed method approach are needed in order to get in-depth information on family change in Africa. More multi-level studies should be conducted on family change in Africa. Moreover, longitudinal studies are needed to examine family changes over time.

\section{Conclusion}

This review provided an overview of the literature on determinants and consequences of family changes in Africa. The review confirmed that there is family transition in Africa due to a plethora of reasons. Family in Africa is a resilient institution and the changes it is facing are attributed to social and economic conditions such as rising education levels, female labour force participation, economic challenges, urbanisation and migration. Increase in level of education attained by women and their participation in the labour force has not only changed their roles in families but marriage patterns. Furthermore, labour migration has changed a lot of families, resulting in single parent families that are becoming more common. HIV/AIDS related mortality and morbidity has altered the structure of many families as it is leading to increased marital dissolution and orphanhood. New laws on homosexuality have led to an emergence to families that were not previously considered as families in South Africa. Family changes have an impact on children's education, child survival as well as sexual behaviour of the youth. Given that family transition is ongoing in Africa and some of the changes have a negative impact, there is need for countries to develop explicit family policies that help improve the wellbeing of the emerging types of families. Future research on family in Africa could be improved by theoretical guidance and being methodologically robust with studies using longitudinal data to examine family change overtime, multilevel analysis and mixed method research approach to get richer information.

\section{Reference}

Adegoke, T., 2010. Socio-cultural Factors as Determinants of Divorce Rates among Women of Reproductive Age in Ibadan Metropolis, Nigeria. Studies of tribes and tribals 8(2), I07-II4.

Akanle O, Omotayo A, Busari D, 20I4. The absentee spouse phenomenon and spousal coping strategies in Ibadan, South-Western Nigeria. African Population Studies 27 (2)Supp (Mar 20I4), 4II423.

Amato, P., 1987. Family Processes in One-Parent, Stepparent, and Intact Families: The Child's Point of View. Journal of Marriage and Family 49(2), 327-337.

Amoateng A,Heaton T, 1989. The Sociodemographic Correlates of the Timing of Divorce in Ghana. Journal of Comparative Family Studies 20 (I), 79-96.

Anglewicz, P., 2012. Migration, Marital Change, and HIV Infection in Malawi. Demography 49 (I), 239265.

Bojuwoye O, Akpan O, 2014. Personal, familial and environmental perspective in chilren's reactions to parental divorce in South Africa. Journal of Family Studies, I5 (3) 37-4I.

Calves, A., 1999. Marginalization of African Single Mothers in the Marriage Market: Evidence from Cameroon. Population Studies, 53 (3) 29I-30I.

Chuong C, Operario D, 20I2. Challenging household dynamics: Impact of orphanhood, parental Impact of orphanhood, parental arrangements on education in South Africa. Global Public Health 7 (I) $42-57$

Clark S, Hamplova D, 2013. Single Motherhood and Child Mortality in Sub-Saharan Africa: A Life Course Perspective. Demography Vol 50 DOI |0.1007/s | 3524-0| 3-0220-6, pp. I52|-|549.

De Wet, N., 2013. Parent absenteeism and adolescent work in South Africa: An analysis of the levels and determinants of adolescents who work 10 or more hours a week. African Population Studies 27 (I) 70-78.

Defo B, Dimbuene Z, 2012. Influences of Family Structure Dynamics on Sexual Debut in Africa: Implications for Research, Practice and Policies in Reproductive Health and Social Development. 
African Journal of Reproductive Health 16 (2), I47-I72

Departmnet of Social Development, 2012. White paper on families in South Africa, Departmnet of Social Development.

Dintwat, K., 2010. Changing Family Structure in Botswana. Journal of Comparative Family Studies 42(3), 28I-297.

Duflo, E, 2012. Women Empowerment and Economic Development. Journal of Economic Literature 50 (40), I05 I-I 079.

Esping-Andersen G \& Billari F, 2015. Re-theorising Family Demographics. Population and Development Review 4I(I), I-3I.

Fenske, J., 2013. African Polygamy: Past and present, s.l: Center of the study for African economics.

Floyd S, Crampin A, Glynn J, Mwenebabu M, Mnkhondia S, Ngwira B, Zaba B, Fine P, 2008. Tropical Medicine and International Health. The long-term social and economic impact of HIV on the spouses of infected individuals in northern Malawi I 3 (4), 520-53I.

Foster G, Makufa C, Drew R, Kralovec E, 1997. Factors leading to the establishment of childheaded households: the case of Zimbabwe. Health Transition Review,7 (2) I55-I68.

Frantz J, Sixaba J, Smith M, 2015. A Systematic Review of the Relationship Between Family Structure and Health Risk Behaviours Amongst Young People: An African Perspective. The Open Family Studies Journal I5 (I), 3-I I.

Garenne M, 2014. Trends in Marriage and Contraception in Sub-Saharan Africa: A Longitudinal Perspective on Factors of Fertility Decline, Maryland: DHS Analytical Studies No. 42.

Garenne, M., 2004. Age at marriage and modernisation in sub-Saharan Africa. Southern African Journal of Demography 9 (2), 59-79.

Goebel A, Dodson B, Hill T, 2010. Urban advantage or Urban penalty?A case study of female-headed households in a South African city. Health and Place 16 (3), 573-580.

Grant M, Yeatman S, 20I4. The Impact of Family Transitions on Child Fostering in Rural Malawi. Demography 5I (I), 205-228.

Grant M, Yeatman S, 20I2. The relationship between orphanhood and child fostering in sub-Saharan Africa, 1990s-2000s. Population Studies 66 (3), 279-295.

Ha W, Salama P, Gwavuya S, 2015. The impact of orphanhood on education attendance: evidence from Zimbabwe. International Journal of Educational Development Vol 40, pp. 59-70.

Hanson T, McLanahan S, Thomson E, 1996. Double Jeopardy: Parental Conflict and Stepfamily
Outcomes for Children. Journal of Marriage and Family 58 (I), I $4 \mathrm{I}-154$.

Hattori M, Larsen U, 2007. Motherhood Status and Union Formation in Moshi, Tanzania 2002-2003. Population Studies, 6I (2) I85-I99.

Hayase Y, Liaw K, 1997. Factors on polygamy in subSaharan Africa findings based on the demographic and health surveys. The Developing Economies35 (3), 293-327.

Heaton T, Hirschl T, 1999. Dr. George Kurianis collaborating with JSTOR to digitize, preserve and extendThe Trajectory Of Family Change In Nigeria. Journal of Comparative Family Studies 30 (I), 35-55.

Hölscher D, Kasiram M, Sathiparsad R, 2009. "Deserving" children, "Udeerving" mothers? multiple perpectives on the child support grant. Social Work 4 (I), II-25.

Hosegood V, Floyd S, Marston M, Hill C, McGrath N, Isingo R, Crampin A, Zaba B, 2007. CommitteeThe Effects of High HIV Prevalence on Orphanhood and Living Arrangements of Children in Malawi, Tanzania, and South Africa. Population Studies,6I (3) 327-336.

Ikamari, L., 2005. The effect of education on the timing of marriage in Kenya. Demographic Research 12 (I), I-28.

Izugbara, C., 20|4. Whose child is dying? Household characteristics and under-5 mortality in Nigeria. South African Journal of Child Health 8 (I), 16-22.

Jordan N, Patel L, Hochfeld T, 20I4. Early motherhood in Soweto: The nexus between the child support grant and developmental social work services. Social Work 50 (3), 390-409.

Katapa, R., 2006. A comparison of female-headed and male-headed households and poverty implications in Tanzania. Journal of Biosocial Science 38 (3), 327-339.

Kimani E, Kombo K, 20I0. Challenges facing nuclear families with absent fathers in Gatundu Northen District, Central Kenya. The African Symbosium: An online journal of the African Educational Research Network 10 (2), pp. II-25.

Lachaud J, LeGrand T, Adjiwanou V, Kobiané J, 2014. Family size and intra-family inequalities in education in Ouagadougou. Demographic Researc 31 (49), | $455-1476$.

Lesthaeghe, R., 2010. The Unfolding Story of the Second Demographic Transition. Population an Developmne Review 36 (2), 2 I I - 25 I.

Lubbe, C., 2007. Mothers, fathers or parents: Samegendered families in South Africa. South African Journal of Psychology 37 (2), 260-283.

Lubbe, C., 2008. The Experiences of Children Growing up in Lesbian-Headed Families in South 
Africa. Journal of GLBT Family Studies,4 (3) 355 372.

Madhavan S, Schatz E, 201I. Headship of older persons in the context of HIV/AIDS in South Africa. African Population Studies 25 (2), 440456.

Madhavan S, Schatz E, 2007. Coping with change: Household structure and composition in rural South Africa, 1992 - 2003. Scandanivian Journal of Public Health Vol 69 supp August doi: I0.1080//403495070। 355627,. 85-93 .

Makiwane M, Desmond C, Richter L, Udjo E, 2006. Is the Child Support Grant associated with an increase in teenage fertility in South Africa? Evidence from national surveys and administrative data, Pretoria: Human Sciences Research Council.

Meintjes H, Hall K, Marera D, Boulle A, 2010. Orphans of the AIDS epidemic? The extent, nature and circumstances of child-headed households. AIDS Care Vol 22 (I), pp. 40-49.

Mere, A., 1976. Contemporary changes in the Igbo family system. International Journal of Sociology of the Family, 6 (2) I5I-I66.

Ministry of Finance, Planning and Economic Development, 2008. National policy for social transformation and sustainable development, Kampala: Ministry of Finance, Planning and Economic Development.

Modo, I., 200I. Migrant Culture and Changing Face of Family Structure in Lesotho. Journal of Comparative Family Studies,32 (3), 443-452.

Mokomane Z, 2005. Cohabitation in Botswana: An Alternative or a Prelude. African Population Studies 20 (I), pp. 19-37.

Mokomane, Z., 2006. Cohabiting Unions in SubSaharan Africa: Explaining Botswana's Exceptionality. Journal of Comparative Family Studies, 37 (I), 25-42.

Monasch R, Boerma J, 2004. Orphanhood and childcare patterns in sub-Saharan Africa: an analysis of national surveys from 40 countries. AIDS 2004, 18 (2), 55-65.

Montgomery C, Hosegood V, Busza J, Timæus I, 2006. Men's involvement in the South African family: Engendering change in the AIDS era. Social Science \& Medicine Vol 62, p. 24I I-24I9.

Moore E, Govender J, 2013. Marriage and Cohabitation in South Africa: An Enriching Explanation?. Joumal of Comparative Family Studies , pp. 623-640.

Moore, E., 2013. Transmission and Change in South African Motherhood: Black Mothers in ThreeGenerational Cape Town Families. Journal of Southern African Studies 39 (I), I5 I-I70.
Mturi A, Kembo J, 20I I. Falling Fertility and increase in Use of Contraception in Zimbabwe. African Journal of Reproductive Health I5 (2) 3I-44.

Muleta A, Derressa D, 20/4. Female Headed Households and Poverty in Rural Ethiopia. Science, Technology and Arts Research Journal 3 (I), I52-I55.

National Population Counci, 1994. National Population Policy, Accra: National Population Council.

Ntaganira J, Hass L, Hosener S, Brown L, Mock N, 20I2. Sexual risk behaviors among youth heads of household in Gikongoro, south province of Rwanda. BMC Public Health Vol 12:225, pp. I-I3.

Odimegwu C, Adedini S, 2013. Do Family Structure and Poverty Affect Sexual Risk Behaviors of Undergraduate Students in Nigeria?. African Journal of Reproductive Health 17 (4), pp. 137149.

Omariba D, B. M., 2007. Family Structure and Child Mortality in Sub-Saharan Africa: Cross-National Effects of Polygyny. Journal of Marriage and Family Vol 69, p. 528-543.

Onuche J, 2009. Same Sex Marriage in Nigeria: A Philosophical Analysis. International Journal of Humanities and Social Science Vol 3 No 12, pp. 9l-98.

Operario D, Underhill K, Chuong C, Cluver L, 20I I. HIV infection and sexual risk behaviour among youth who have experienced orphanhood: systematic review and meta-analysis. Journal of the International AIDS Society I4 (25), I-I I.

Oppong, C., 1977. A Note from Ghana on Chains of Change in Family Systems and Family Size. Journal of Marriage and Family,39 (3) 615-62I.

Palamuleni M, Adebowale A, 20I4. Patterns of premarital childbearing among unmarried female youths in sub-Saharan Africa. Scientific Research and Essays, 9 ( I0) 42I-430.

Palamuleni M, Adebowale A, 2014. Women empowerment and the current use of long acting and permanent contraceptive: Evidence from 2010 Malawi Demographic and Health Survey. Malawi Medical Journal 26 (3), 63-70.

Palamuleni M, 20I0. Recent Marriage patterns in South Africa 1996-2007. Bangladesh e-Journal of Sociology, 7 (I) 47-70.

Palamuleni, M., 20II. Socioeconomic determinants of age at marriage in Malawi. International Journal of Sociology and Anthropology 3 (7), 224-235.

Patel L, Hochfeld T, 20II. It buys food but does it change gender relations? Child Support Grants in Soweto, South Africa. Gender \& Development 9 (2), 229-240.

Pillai V, Sharma Y, 20I3. Child fosterage among Zambian families. Vulnerable Children and Youth 
Studies: An International Interdisciplinary Journal for Research, Policy and Care 8 (4), 362-365.

Porter L, Hao L, Bishai D, Serwadda D, Wawer M, Lutalo T, Gray R, 2004. HIV Status and Union Dissolution in Sub-Saharan Africa: The Case of Rakai, Uganda. Demography,4I (3), 465-482.

Posel D, Casale D, 2003. What has been happening to internal labour migration in South Africa, 19931999?. The South African Journal of Economics 7I (3), 455-479.

Posel D, Rudwick S, Casale D , 20II. Is marriage a dying institution in South Africa? Exploring changes in marriage in the context of ilobolo payments. Agenda: Empowering women for gender equity 25 (I), I02-III.

Reniers, G., 2003. Divorce and remarriage in rural Malawi. Demographic Research Special collection I article 6, pp. I73-206.

Rothmann, J., 20II. South African gay fathers' parenting practices: from pathology to 'normalisation'. Acta Academica 43 (I), 39-78.

Schmeer K, 20II. The Child Health Disadvantage of Parental Cohabitation. Journal of Marriage and Family Vol 73 (February 20I I), p. I8I - 193.

Shapiro D, Gebreselassie T, 2008. Fertility Transition in Sub-Saharan Africa: Falling and Stalling. African Population Studies 22 (2), pp. 3-23.

Siqwana-Ndulo, N., 1998. Rural African Family Structure in the Eastern Cape Province, South Africa. Journal of Comparative Family Studies, 29 (2), 407-4I7.

Smith-Greenaway E, Trinitapoli J, 2014. Polygynous Contexts, Family Structure, and Infant Mortality in
sub-Saharan Africa. Demography $5 \mathrm{I}$ (2), 34I366.

Smit, R., 2002. The Changing Role of the Husband/Father in the Dual-Earner Family in South Africa. Journal of Comparative Family Studies, 33 (3), 40I-4I5.

Spruijt E, de Goede M, 1997. Transitions in family structure and adolescent well-being. Adolescence 32 (I 28), 897-9II.

Takyi, B., 200I. Marital Insability In An African Society: Exploring The Factors That Influence Divorce Processes in Ghana. Sociological Focus,34 (I), 77-96.

Takyi, B., 2007. Matrilineal Family Ties and Marital Dissolution in Ghana. Journal of Family Issues 28 (5) 682-705.

Tangwe, P., 2013. The Impact of the Old Age Grant on Rural Households in Nkonkobe Municipality in the Eastern Cape Province of South Africa. Mediterranean Journal of Social Sciences 4 (I3) 627-635.

Thiombiano B, LeGrand T, Kobiané J, 2013. Effects of parental union dissolution on child mortality and schooling in Burkina Faso. Demographic Research 29 (29), 797-8I 6.

Tilson D, Larsen U, 2000. Divorce in Ethiopia: The Impact of early marriage and childnessness. Journal of Biosocial Science:, pp. 355-372.

Wusu O, Isiugo-Abanihe U, 2006. Interconnections among changing family structure, childrearing and fertility behaviour among the Ogu, Southwestern Nigeria: A qualitative study. Demographic Research I4 (8), . I39-I58.

\section{Appendices}

Table I: Summary of the studies

Sample size
Quantitative research $>100$
Quantitative research $<100$
Over 1000
Research approach
Quantitative
Qualitative
Mixed method
Design
Cross sectional
Longitudinal

\section{Outcome variables}

Demographic

Family types and relationships

Sexual behaviour

$\begin{array}{ll}\text { Frequency } & \text { Percentage } \\ 2 & 4 \% \\ 48 & 96 \% \\ 38 & 76 \% \\ & \\ 50 & 72 \% \\ 14 & 20 \% \\ 5 & 7 \% \\ 58 & \\ 6 & 91 \% \\ & 9 \%\end{array}$

$46 \%$


African Population Studies Vol. 3I, No. I,(Supp. 2), 2017

$\begin{array}{lll}\text { Health outcomes } & 4 & 6 \% \\ \text { Sex roles } & 4 & 6 \% \\ \text { Attitudes } & 3 & 4 \% \\ \begin{array}{l}\text { Theory } \\ \text { Utilized theory }\end{array} & 19 & 28 \% \\ \begin{array}{l}\text { Fertility theories } \\ \text { Quantitative studies data sources }\end{array} & 6 & 18 \% \\ \begin{array}{l}\text { Primary data } \\ \text { Secondary }\end{array} & 10 & 20 \% \\ \begin{array}{l}\text { Demographic and Health Survey } \\ \text { Qualitative studies data sources }\end{array} & 40 & 80 \% \\ \begin{array}{l}\text { Primary } \\ \text { Secondary (desktop review of literature) }\end{array} & 6 & 34 \% \\ \text { Quantitative statistical methods } & 9 & 64 \% \\ \begin{array}{l}\text { Descriptive } \\ \text { Bivariate }\end{array} & 6 & 36 \% \\ \text { Multivariate } & 4 & 12 \% \\ & 40 & 8 \% \\ & & 80 \%\end{array}$


Table 2: Descriptions and findings of research addressing changes in family formation

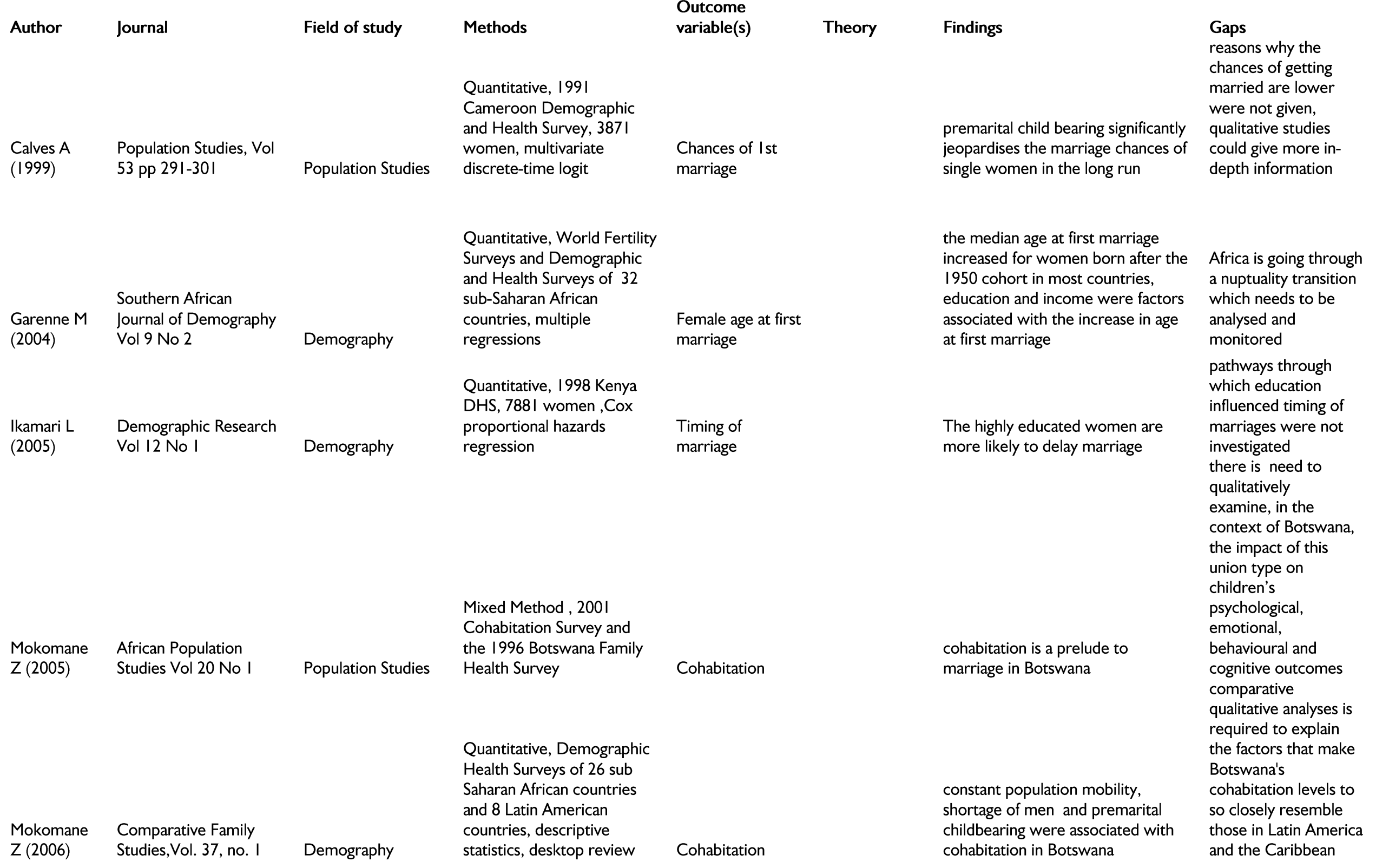


Quantitative, 2002-2003

Moshi Infertility Survey,

2019 women, multivariate

\section{Hattori M}

\&Larsen U Population Studies, Vol.

(2007)

6I, No. 2,

Population Studies

discrete time logistic

regression

Economic

theory of

fertility

(Becker

1960)

Dintwant K Family Studies, Vol. 4I,

(1956)

\section{Journal of Comparative}

Demography and

Population Studies

Qualitative, desktop review mothers for 5 or more years (about

South African censuses of 1996 and 2001 , descriptive statistics, singulate mean

Palamuleni Bangladesh e-Journal of statistics, singulate mean

M (2010) Sociology Vol $7 \mathrm{Nol} \quad$ Sociology

Posel $D$ et al (20II)

Agenda Vol 25 No I

Moore E \& Govender R Comparative Family (2013) Studies Vol 44 no 5

\section{Marriage}

\section{Qualitative, desktop review Marriage}

Quantitative South African Social Attitudes Survey 2005, 3500 respondents,

multinomial logistic regression
Sociology
Cohabitation mean age at marriage for men and
Women who had been single two-thirds of women with a premarital birth) were significantly less likely than women without children to enter into a first union.

Family structure has been changing because of labour migration, HIV,

Davis/ Blake inheritance patterns , fertility

decline and marriage

marriage an

further studies that distinguish between

marriage and

cohabitation should be considered women in South Africa is high and increasing and more men and women are staying single or not marrying at al

Marriage has significantly declined among black people compared to white people because of lobola

reasons for the

decline in marriages More studies should be undertaken in order to understand

the causes and consequences of the changing marriage patterns in South

Africa

The study did not examine changes in marriage in other black cultures besides the Zulus

Age, education, place of residence, race, employment status were

significant determinants of

the study did not examine the impact of migration on marriage and cohabitation 


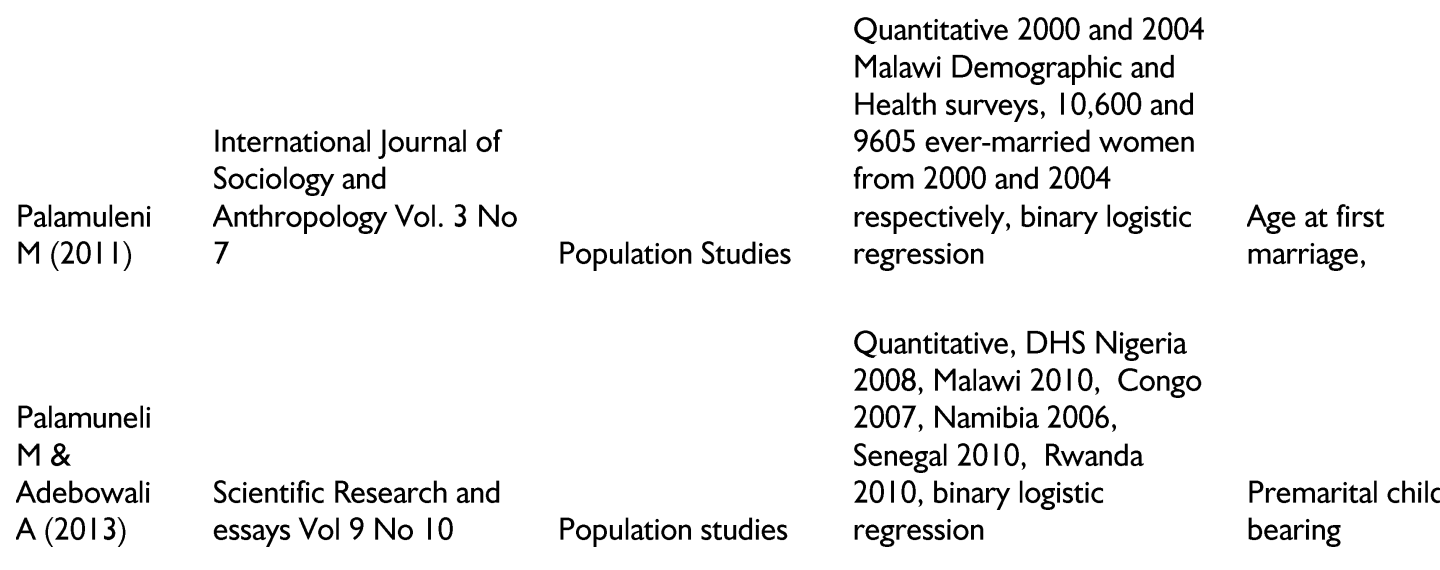

Quantitative 2000 and 2004

Demographic and

from 2000 and 2004

respectively, binary logistic Age at first

Quantitative, DHS Nigeria

2008, Malawi 2010, Congo

2007, Namibia 2006,

2010 , binary logistic

bearing age, region and education are the most important determinants of age at marriage in Malawi

\section{Identified determinants of} premarital chid bearing were contraceptive use education,

religion and early sexual debut
There is need to conduct more studies on the causes and consequences of early marriage in Malawi. These future studies should not only be multidisciplinary but also qualitative in nature

The study did not examine regional differences of premarital child bearing in these countries

\section{Table 3: Descriptions and findings of research addressing polygamy}

Author

Journal

International Journal of Sociology of the Family

Mere A (1976)
Vol. 6, No. 2
Field of study

Sociology
Methods

Polygyny,

extended family,

parental control,
Qualitative, Review of divorce,

marriages

control,
child

literature variable(s)
Outcome

Theory

Findings

a decline in

polygyny

among the lgbo

because of

religion,

detailed research is

industrialisation needed on Igbo

women's

family

change,

education and emphasizing on areas

delayed such as kin network

Goode (1973) marriages 
African Population Studies Vol. 31, No. I,(Supp. 2), 2017

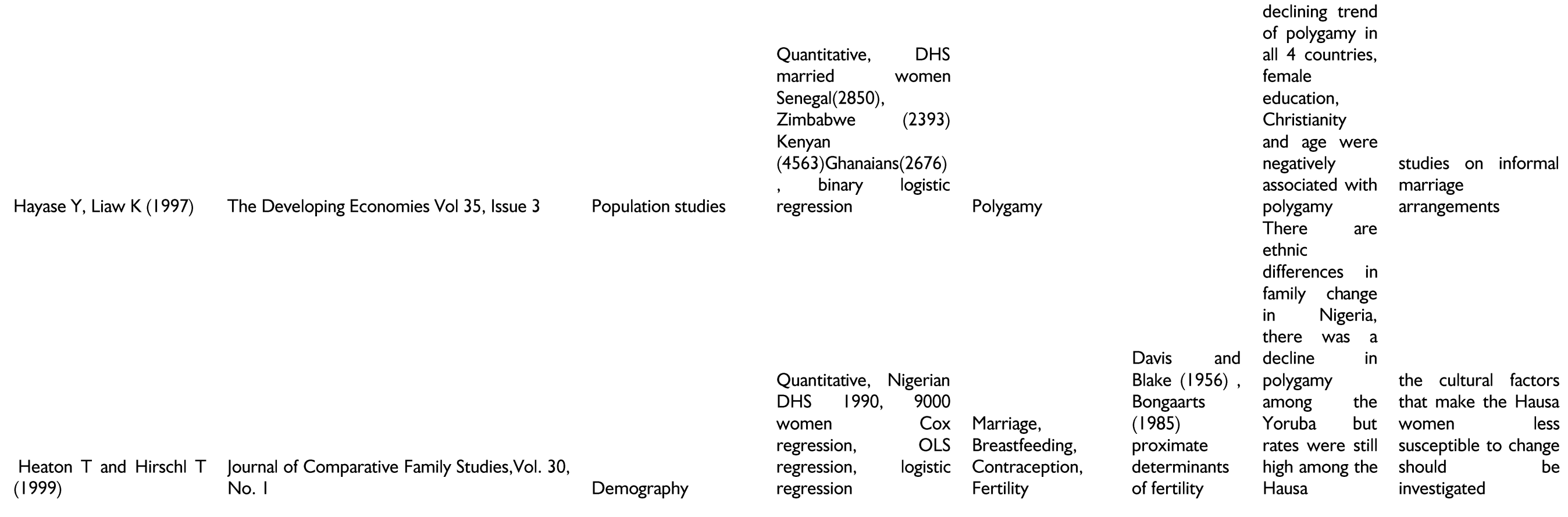

Table 4: Descriptions and findings of research addressing changes in family size

\section{Author}

Journal

Field of study

Methods

Outcome

variable(s)

Quantitative, 393

single, male Attitude

Ghanaian students, towards family

descriptive statistics size. education affects attitude family change was towards family size through inadequately explained and the intervention of attitude more models which include towards type of conjugal and more variables should be marital relationship done 
Journal of Comparative Heaton T and Hirschl T Family Studies, Vol. 30, No. (1999)

Demography
Quanitative, DHS

1990, 9000 women

Cox regression,

OLS regression,

logistic regression

Qualitative, 9 FGD

groups

\section{Quantitative,}

Analysis of three

point Agincourt

Scandinavian Journal of

Madhavan \&Schatz Public Health Vol 69 supp

(2007)

August

Public Health

census data for Household

1992, 1997, 2003, structure and

regression

arriage,

breastfeeding,

fertility

Family structure

Davis and Blake there are ethnic differences

(1956) Bongaarts in family change in Nigeria,

(1985) proximate there are family changes

(1985) proximate there are family changes
determinants of among the Yoruba and the

fertility lbo but not among the Hausa

decline in extended family support leaving child rearing costs as the responsibility of the biological parents so couples now want fewer children

further studies should be done to see how family changes explain fertility behaviour in other parts of sub-Saharan Africa

average household size decreased and the proportion headed by females increased, decrease in families with foster children and materna orphans doubled

further studies should focus on how well families and households composition absorbing children orphaned from HIV/AIDS
24 countries with multiple DHS in Sub Saharan Africa, SUR

Shapiro \&Gebreselassie African Population Studies (2008)
Population studies
Vol. 22 no2 regressions
African Journal of Reproductive Health Vol

Mturi A Kembo J (20II) 15 no 2
Quantitative,

\section{Zimbabwe}

Demographic and

Health Surveys in

1987/88, 1994

1999 and 2005/06,

Population studies logistic regression
06,

http://aps.journals.ac.za

fertility decline is still under way in $65 \%$ of the countries, education, infant Easterlin framework and child mortality, modern for fertility analysis contraceptive use, the (1975), Proximate percentage of women in Determinants of union, place of residence, fertility Bongaarts and time all are significantly (1978) related to fertility levels

the study did not project Fertility decline (1978) how far might fertility fall in sub Saharan Africa
Proximate

determinants of the decline of fertility was fertility (Bongaarts 1978) there is a mismatch between TFR and contraceptive prevalence rate in Zimbabwe which needs to be investigated 
African Population Studies Vol. 3I, No. I,(Supp. 2), 2017

Dintwant K (2010)

Journal of Comparative Demography and

Family Studies, Vol. 4I, No. Population 3
Studies
Qualitative desktop review family structure has been changing because of labour migration, HIV, inheritance reasons for the decline in patterns , fertility decline and Family size reasons for the decline in
marriages were not investigated

Table 5: Descriptions and findings of research addressing same gendered families

Author

Journal

Field of study

Methods

Outcome variable(s)

Theory

Postmodern

Social

Qualitative,

review

Lubbe C(2007)

South African Journal

Psychology of

Psychology of

Same-gendered families
Constructionist

perspective experiences of growing

Qualitative

narrative

inquiry,

Educationa

Lubbe C (2008) Vol 4 No 3

Qualitative, 7 indepth interviews and 5 selfadministered

Rothmann J (20II) Acta Academica Vol 43 No I Sociology
8 up in lesbian headed families
Findings

parenting and family are constructed and performed, structural variables such composition of families and the division of parental performances are less important than process and variables such as the quality of relationships and the quality of care given to the children

further scientific studies need to be done on same gendered families and

heteronormative factors influence them longitudinal studies are needed to see if children who were these experiences interviewed were very change overtime, aware of the tendency of similar studies on people to react in different gay headed families ways to the notion of also need to be lesbian-headed families

Generativity theory education, skills and study did not show (Brotherson 2007, support from marital and the experiences of Dollahite et al 1997, life partners had influence children with gay Hawkins \& Dollahite on paternal involvement of parents as it focused 1997) on the gay men only 
Table 6: Descriptions and findings of research addressing changes in family roles

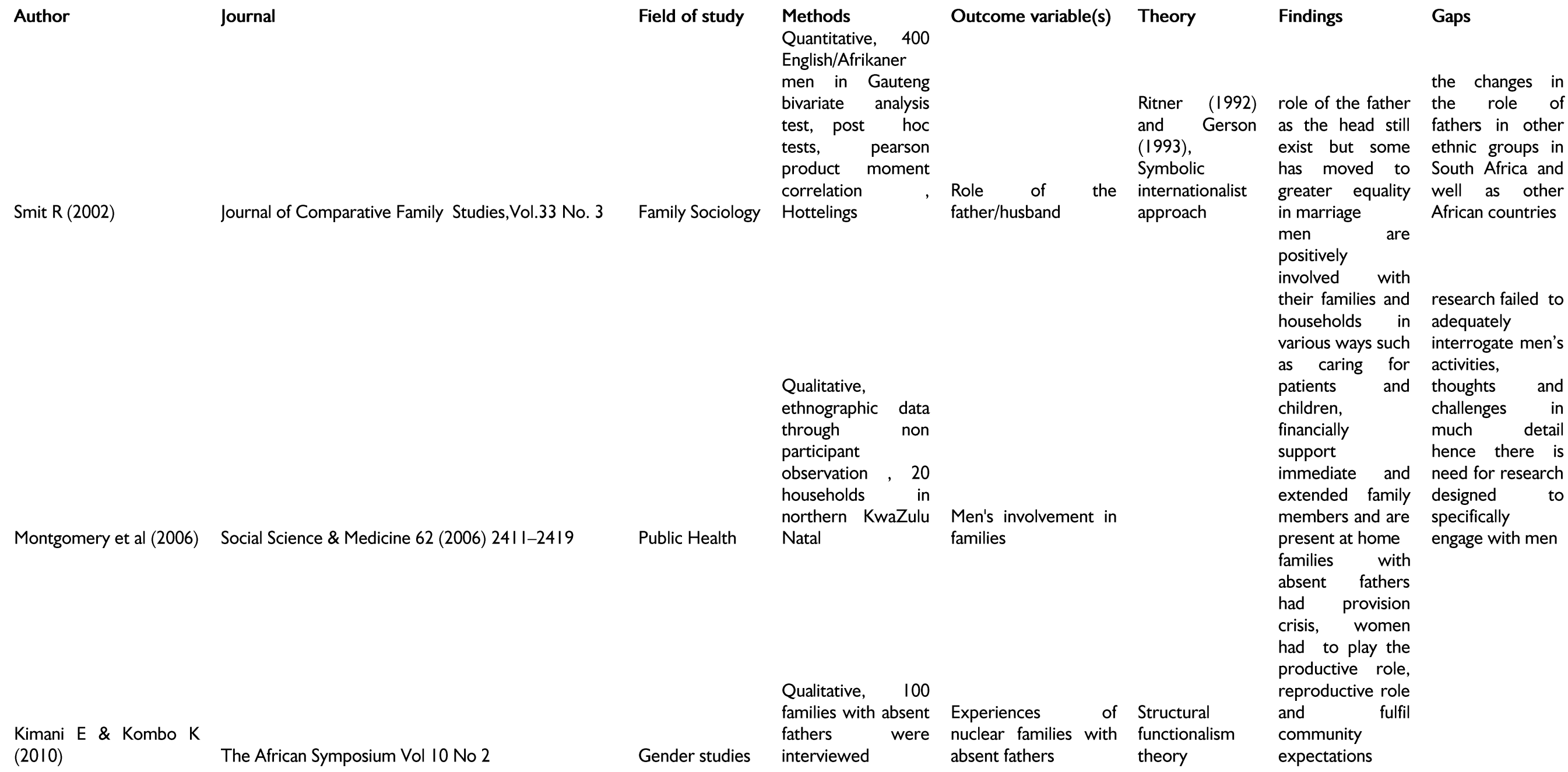


Qualitative, life history interviews and case studies of women from 3

Moore E (2013) Journal of Southern African Studies, 2013 Vol 39 No I Sociology generations

Mothering practice examine how

state

concerning

women, work and childcare, or

nature

of 'political

motherly care motherhood'

changed over the affects the way

generations, all mothering is

generations of constructed in

mothers needed the everyday

support for experiences of

different reasons individuals

Table 7: Descriptions and findings of research addressing orphanhood and child headed households

\section{Author}

G. Foster et al (1997)

Health Transition Review, Vol 7 No 2 (1997)

Monasch \& Boerma (2004) AIDS Vol I8 No 2
Field of study

\section{Methods}

Outcome variable(s)

Child care patterns

\begin{tabular}{|c|c|}
\hline 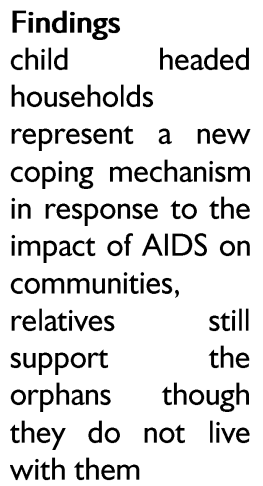 & $\begin{array}{l}\text { Gaps } \\
\text { future studies } \\
\text { should clarify } \\
\text { whether child- } \\
\text { headed } \\
\text { households are } \\
\text { being established } \\
\text { in urban areas } \\
\text { following parental } \\
\text { death and the } \\
\text { ways in which } \\
\text { such households } \\
\text { terminate }\end{array}$ \\
\hline $\begin{array}{l}\text { the existing child } \\
\text { care system is } \\
\text { absorbing the } \\
\text { increase of } \\
\text { orphans on a large } \\
\text { scale }\end{array}$ & $\begin{array}{l}\text { study employed } \\
\text { descriptive } \\
\text { statistics, further } \\
\text { studies should } \\
\text { employ inferential } \\
\text { statistics to test } \\
\text { level of } \\
\text { significance of the } \\
\text { results }\end{array}$ \\
\hline
\end{tabular}




\begin{tabular}{|c|c|c|c|c|}
\hline & & & $\begin{array}{l}\text { Quantitative, } \\
\text { Analysis of three } \\
\text { point Agincourt } \\
\text { census data for } \\
\text { 1992, 1997, }\end{array}$ & Household structure \\
\hline Madhavan \&Schatz (2007) & Scandinavian Journal of Public Health Vol 69 supp August & Public Health & $\begin{array}{l}\text { 2003, regression } \\
\text { Quantitative } \\
\text { Longitudinal data } \\
\text { from } \\
\text { Demographic } \\
\text { Surveillance } \\
\text { Systems in } \\
\text { Malawi, South } \\
\text { Africa, Tanzania } \\
\text { 1984-2004, } \\
\text { Poisson }\end{array}$ & and composition \\
\hline Hosegood et al (2007) & Population studies Vol 61 No 3 & Family Demography & $\begin{array}{l}\text { regression } \\
\text { Quantitative, } \\
\text { General } \\
\text { Household } \\
\text { Survey (GHS) f } \\
2002-2006 \text { and } \\
\text { the biannual } \\
\text { Labour Force } \\
\text { Survey (LFS) } \\
2000 \quad-2007 \text {, } \\
\text { Wilcoxon rank- }\end{array}$ & Orphanhood \\
\hline Meintjes $\mathrm{H}$ et al (2010) & $\begin{array}{l}\text { AlDS } \\
\text { Vol. 22, No. I }\end{array}$ & Public Health & $\begin{array}{l}\text { sum test, chi } \\
\text { square }\end{array}$ & $\begin{array}{l}\text { Child } \\
\text { households }\end{array}$ \\
\hline
\end{tabular}

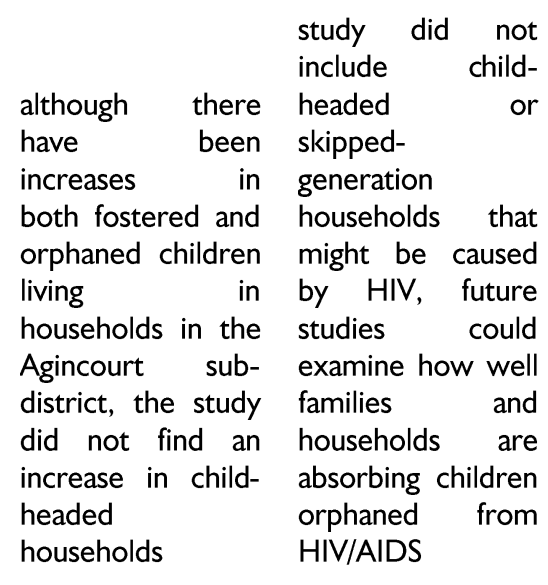

increase in levels

of orphanhood,

no evidence that

child headed

households

increased

no evidence that further studies
that child-only
households are a $\begin{aligned} & \text { could examine the } \\ & \text { rapidly growing }\end{aligned}$
phenomena in socion other
South Africa, such as parental
kinship networks migration and
still provide care the establishment
for children of child-only
affected by HIV households


Table 8: Descriptions and findings of research addressing single motherhood and female headed households
Author
Journal
Field of study
Methods
Outcome variable(s)
Theory

further studies in African urban and rural settings need to look at

Journal of
Comparative

Family Studies

Siqwana-Ndulo N (1998)

Vol. 29, No. 2

Sociology

Mixed method, survey and

interviews of 96

respondents

Household structure

Quantitative, 1991

Cameroon Demographic

and Health Survey, 387I

Population

Studies, Vol 53

Calves A (1999)

pp29I-30I

discrete-time logit

Chances

marriage

of Ist

logit

$62 \%$ of the households were headed by women who were widows, nevermarried wives of migrants and changes

premarital child bearing reasons why the chances of significantly jeopardises getting married are lower were the marriage chances of not given, qualitative studies single women in the long could give more in-depth run information

how individuals and groups are affected by changing social and conomic conditions and how they are responding to these

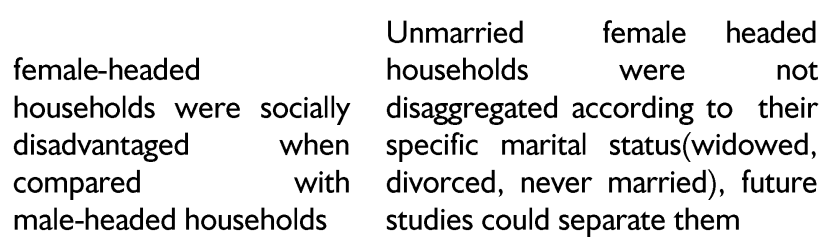




\begin{tabular}{|c|c|c|c|c|c|c|c|}
\hline Hattori M \&Larsen U (2007) & $\begin{array}{l}\text { Population } \\
\text { Studies, vol. 6I, } \\
\text { no. 2, }\end{array}$ & Population Studies & $\begin{array}{l}\text { Quantitative, 2002-2003 } \\
\text { Moshi Infertility Survey, } \\
2019 \text { women, multivariate } \\
\text { discrete time logistic } \\
\text { regression }\end{array}$ & 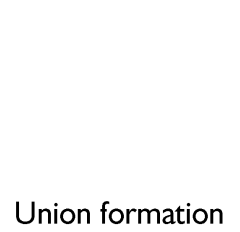 & $\begin{array}{l}\text { Economic } \\
\text { theory of } \\
\text { fertility } \\
\text { (Becker } \\
\text { 1960) }\end{array}$ & $\begin{array}{l}\text { women who had bee } \\
\text { single mothers for } 5 \\
\text { more years wer } \\
\text { significantly less likely tha } \\
\text { women without childre } \\
\text { to enter into a first union. }\end{array}$ & 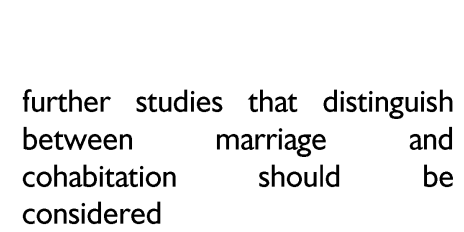 \\
\hline
\end{tabular}

\begin{tabular}{|c|c|c|c|c|}
\hline 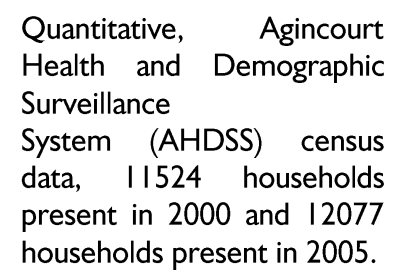 & $\begin{array}{l}\text { d aged } \\
\text { buseholds }\end{array}$ & $\begin{array}{l}\text { Altruistic } \\
\text { model of } \\
\text { household } \\
\text { (Becker } \\
\text { 1974) }\end{array}$ & $\begin{array}{l}\text { there were more } \\
\text { households headed by } \\
\text { women compared to men } \\
\text { and this difference is } \\
\text { increasing }\end{array}$ & $\begin{array}{l}\text { there is need for longitudinal } \\
\text { analysis of change in the roles of } \\
\text { the } \\
\text { elderly, need for focused analysis } \\
\text { on households affected by HIV on } \\
\text { the changing role of the elderly }\end{array}$ \\
\hline
\end{tabular}

Table 9: Descriptions and findings of research addressing the shift towards nuclear families
Author
Journal
Field of study
Methods

Outcome variable(s) Theory Findings

Gaps
further studies in
African urban and
rural settings need to
look at how
individuals and
groups are affected
by changing social
and economic
conditions and how
they are responding
to these changes

Mixed method,
survey and
interviews of 96
respondents

respondents
Household structure

Black people are not
experiencing a trend
of the nuclear
family

to these changes 
African Population Studies Vol. 31, No. I,(Supp. 2), 2017

Monasch \& Boerma

(2004)

AIDS Vol 18 No 2

Public Health

Indicator Cluster

Surveys (MICS)

and

14

Demographic and

Health Surveys,

descriptive

analysis

Child care patterns

Scandanivian Journal of Public Health Vol 69 supp

Madhavan \&Schatz (2007) August

Public Health

point Agincourt

census data for

1992, 1997, 2003.

regression

Household structure

and composition

Quantitative

Longitudinal data

from

3

Demographic

Surveillance

Systems

in

Malawi, South

Africa, Tanzania

1984-2004,

Hosegood et al (2007) Population studies Vol 6I No 3

AIDS

Meintjes $\mathrm{H}$ et al (20I0)

Vol. 22, No. 1
Care

Public Health
Poisson regressi

\section{General}

Household

Survey (GHS) f

$2002-2006$ and

the biannual

Labour Force

Survey (LFS) 2000

-2007, Wilcoxon

rank-sum test, ch

square
Living arrangements

of orphans

Child headed

study employed

The existing child descriptive statistics, care system which further studies is the extended should employ family is absorbing inferential statistics the increase of to test level of orphans on a large significance of the scale

\section{results}

study did not include

Even though there child-headed or

have been increases skipped-generation

in

fostered and might be caused by

children HIV, future studies living in households could focus on how in the Agincourt well families and sub-district, the households are study did not find an absorbing children increase in child- orphaned from headed households HIV/AIDS No evidence that

child headed

households

increased despite of high incidence of

orphanhood

showing that

extended families

are the caregivers ,

there was evidence

of non-orphans

living with extended

family

No evidence that future studies should

that child-only consider the

households are a association

rapidly growing between other

phenomena in South factors such as

Africa, kinship parental movement networks still and

provide care for the establishment of children affected by child-only

HIV 
Table 10: Descriptions and findings of research addressing marital dissolution

\begin{tabular}{|c|c|c|c|c|c|c|c|}
\hline Author & Journal & Field of study & Methods & $\begin{array}{l}\text { Outcome } \\
\text { variable(s) }\end{array}$ & Theory & Findings & Gaps \\
\hline $\begin{array}{l}\text { Amoateng \& Heaton } \\
\text { (1989) }\end{array}$ & $\begin{array}{l}\text { Comparative Family Studies Vol } 20 \\
\text { no I }\end{array}$ & Social Demography & $\begin{array}{l}\text { Quantitative, } 1979 / 89 \\
\text { Ghana Fertility Survey, } \\
7500 \text { households, life } \\
\text { table regression }\end{array}$ & Divorce & $\begin{array}{l}\text { Theory of } \\
\text { marital } \\
\text { instability } \\
\text { (Becker 1976) }\end{array}$ & $\begin{array}{l}\text { age at marriage, } \\
\text { education, religion, } \\
\text { region, structure of } \\
\text { kinship were associated } \\
\text { with divorce }\end{array}$ & $\begin{array}{l}\text { the association between } \\
\text { number of children and } \\
\text { divorce was not examined }\end{array}$ \\
\hline $\begin{array}{l}\text { Tilson D \& Larsen U } \\
\text { (2000) }\end{array}$ & $\begin{array}{l}\text { Journal of Biosocial Science Vol } 32 \\
\text { no } 3\end{array}$ & & $\begin{array}{lr}\text { Quantitative, } & 1990 \\
\text { Ethiopia } & \text { National } \\
\text { Family } & \text { and } \\
\text { Fertility } & \text { Survey, } 8757 \\
\text { women, Cox models }\end{array}$ & Divorce & & $\begin{array}{l}\text { childlessness and early } \\
\text { marriage were significant } \\
\text { determinants of divorce }\end{array}$ & $\begin{array}{l}2 \text { regions were omitted } \\
\text { when collecting data } \\
\text { because of civil war and a } \\
\text { further study could be } \\
\text { conducted in those } \\
\text { regions }\end{array}$ \\
\hline Takyi B (200I) & Sociological Focus,Vol. 34, No. I & Sociology & $\begin{array}{l}\text { Quantitative, Ghana } \\
\text { Demographic and } \\
\text { Health Survey } 1993 / 4, \\
4562 \text { women, binary } \\
\text { logistic regression }\end{array}$ & Divorce & $\begin{array}{l}\text { Caldwell (1982) } \\
\text { Theory of } \\
\text { fertility decline }\end{array}$ & $\begin{array}{l}\text { Divorce was associated } \\
\text { with kinship ties, urban } \\
\text { residence, religion, parity } \\
\text { and education }\end{array}$ & $\begin{array}{l}\text { Studies need to be done } \\
\text { on the association } \\
\text { between cross ethnic } \\
\text { marriages and divorce }\end{array}$ \\
\hline Reniers (2003) & Demographic Research & Demography & $\begin{array}{l}\text { Quantitative, Malawi } \\
\text { Diffusion and Ideational } \\
\text { Change Project I } 342 \\
\text { ever-married women, } \\
\text { cox regression }\end{array}$ & $\begin{array}{l}\text { Divorce, } \\
\text { remarriage }\end{array}$ & & $\begin{array}{l}\begin{array}{l}\text { childlessness, } \\
\text { systems, }\end{array} \\
\text { empowerment, age at } \\
\text { marriage polygyny, } \\
\text { religion were associated } \\
\text { with divorce }\end{array}$ & $\begin{array}{l}\text { further studies on the } \\
\text { association between HIV } \\
\text { and divorce }\end{array}$ \\
\hline Porter et al (2004) & Demography, Vol 4I no 3 & Demography & $\begin{array}{l}\text { Quantitative, data from } \\
\text { a Random Control } \\
\text { Trial, } 6433 \text { women , } \\
\text { Life table analysis, } \\
\text { multinomial regression }\end{array}$ & $\begin{array}{l}\text { Divorce/separation, } \\
\text { widowhood }\end{array}$ & & $\begin{array}{l}\text { marriage dissolution was } \\
\text { found to be more } \\
\text { common among HIV- } \\
\text { infected women }\end{array}$ & $\begin{array}{l}\text { future studies should } \\
\text { examine whether } \\
\text { discovery and disclosure } \\
\text { of HIV status influences } \\
\text { patterns of family } \\
\text { formation and dissolution }\end{array}$ \\
\hline
\end{tabular}


Takyi G \& Gyimah S Journal of Family Issues Vol 28 no (2007)

\section{Tropical Medicine and}

Floyd S et al (2008) International Health, Vol I 3 no 4

Studies of tribes and tribals $\mathrm{Vol} 8$ No 2
T Adegoke (2010)
Social Demography
Ghana Demographic
and Health Surveys

and Health Surveys

1993, 1998, and 2003,

sample size was 3598

3593,3652 and 4049

respectively, binary

logistic regression

$\begin{array}{lll} & \begin{array}{l}\text { results indicate a qualitative studies are } \\ \text { significantly higher risk of }\end{array} \\ \text { Rational choice } & \text { divorce to examine the } \\ \text { nemong } & \text { specific pathways in which } \\ \text { theory (Klein \& } & \text { matrilineal than non- } & \text { matriliny affects marital } \\ \text { White, 2002) matrilineal women } & \text { outcomes }\end{array}$

the effect of couple $26 \%$ of the wives of concordancy/discordancy HIV-positive index men on outcomes such as experienced household remarriage were not dissolution examined

$\begin{array}{lrl}\text { Cultural } & \text { factors, } & \\ \text { education and } & \text { Study did not include } \\ \text { childlessness } & \text { were } & \text { economic empowerment } \\ \text { significant determinant of } & \text { of women as a } \\ \text { divorce } & \text { determinant }\end{array}$

Quantitative Population Remarriage, based survey 197 HIV household positive people and structure, 397 HIV negative, widowhood, survival analysis divorce, migration

Quantitative , 226 women of

reproductive multiple regression

Divorce

Table II: Descriptions and findings of research addressing migration, urbanisation and family change

Author

Journal

Field of study

Methods

$\begin{array}{lll}\begin{array}{l}\text { Quantitative, } \\ \text { household heads, } \\ \text { descriptive statistics }\end{array} & \text { Family } \\ \text { structure }\end{array}$

Outcome

variable(s)

Theory

Findings

Gaps

labour migration of a the study was restricted to spouse is associated family heads and could not with marital tell us the responses of dissolution and individuals who are not consequently a heads, future studies should weakened family be conducted on individuals structure who may not be family heads 
Posel D \& Casale The South African Journal of Economics D (2003) Vol 7I No 3
Quantitative, Project for Statistics on Living Standards and

Development $\quad(9000$

households) October

Household Surveys

between 1993 and 1999 Labour

conducted by Stats SA, migration
The increase in labour

migration has been

driven by the rising

proportion of women future research using good

leaving rural areas to quality data that is produced

work

family structure has

Demography

Journal of Comparative Family and Population Qualitative, desktop Family

Studies review

structure

Davis/ Blake been changing because

Dintwant K (20I0) Studies,Vol. 4I, No. 3

of labour migration

there should be more attempts to understand the relations between HIV

Malawi Diffusion and

Ideational Change

Project,4528 people

Anglewicz

(2012)

Demography Vol 49 No I

and 402 migrants,
Demography binary logistic regression Migration
HIV

positive infection and marital patterns

individuals are more in Africa as well as the

likely to migrate due to collection and examination

marital dissolutions of longitudinal data on

and remarriage

migrants and non-migrants

Table 12: Descriptions and findings of research addressing family change and education

\begin{tabular}{|c|c|c|c|c|c|c|}
\hline Kimani E \& Kombo K (20I0) & The African Symposium Vol I0 No 2 & Field of study & $\begin{array}{l}\text { Methods } \\
\text { Qualitative, } 100 \\
\text { families with } \\
\text { absent fathers } \\
\text { were } \\
\text { interviewed }\end{array}$ & $\begin{array}{l}\text { Outcome variable(s) } \\
\text { Experiences of nuclear } \\
\text { families with absent } \\
\text { fathers }\end{array}$ & $\begin{array}{l}\text { Structural } \\
\text { functionalism } \\
\text { theory }\end{array}$ & $\begin{array}{l}\text { Findings } \\
\text { youth with } \\
\text { absent fathers } \\
\text { had poor } \\
\text { academic } \\
\text { performance }\end{array}$ \\
\hline
\end{tabular}


African Population Studies Vol. 3I, No. I,(Supp. 2), 2017

Quantitative,

South

Africa

Demographic

and Health

Surveys (DHS)

5592 children,

hierarchical

logistic

Chuong C \&Operario D

Global Public Health Vol. 7, No. I

Public Health

regression

Quantitative,

Survey of

Activities of

Young People

(SAYP)(20I0), I7

372 youth, 10 or more hours of

African Population Studies Vol 27,

De Wet N (2013)

$$
\text { (Apr 2013) }
$$

Demography

logistic

regression

Quantitative

Migration and

Urban

Integration

Survey of

Burkina Faso

17,399 children,

survival analysis

,Kaplan-Meier

\&piecewise

exponential

models

Mixed methods approach, 350 responded to questionnaires

and 10 people

were
Akanle O, Adebayo A, African Population Studies Vol 27, Busari D (20|4)
Supp 2
Population Studies interviewed
Educational delay

labour

force

Starting school, Child mortality

\begin{tabular}{|c|c|}
\hline & $\begin{array}{l}\text { clarification of } \\
\text { specific pathways } \\
\text { that might influence }\end{array}$ \\
\hline $\begin{array}{l}\text { Educational delay } \\
\text { is largely } \\
\text { influenced by } \\
\text { changes in family } \\
\text { support and } \\
\text { structure } \\
\text { an association } \\
\text { was found } \\
\text { between parent } \\
\text { absenteeism and } \\
\text { working for I0 } \\
\text { or more hours a } \\
\text { week thus } \\
\text { jeopardising } \\
\text { school } \\
\text { completion }\end{array}$ & $\begin{array}{l}\text { the association } \\
\text { between maternal } \\
\text { versus } \\
\text { paternal absence on } \\
\text { children's } \\
\text { educational progress }\end{array}$ \\
\hline $\begin{array}{l}\text { children of } \\
\text { divorced parents } \\
\text { had a lower } \\
\text { probability of } \\
\text { entering school } \\
\text { compared to } \\
\text { those with intact } \\
\text { parents }\end{array}$ & $\begin{array}{l}\text { future studies } \\
\text { should examine } \\
\text { whether there is a } \\
\text { difference between } \\
\text { married parents and } \\
\text { cohabiting couples } \\
\text { in terms of child } \\
\text { mortality }\end{array}$ \\
\hline
\end{tabular}

Modernisation

Theory, (Rostow

1953, 1960) \&

Attachment

theory

and Children's

academic

further studies

academic

should consider the

Spouse absenteeism, (Lowenstein

negatively

is association between

copying mechanisms 2008) spouse absenteeism and HIV 


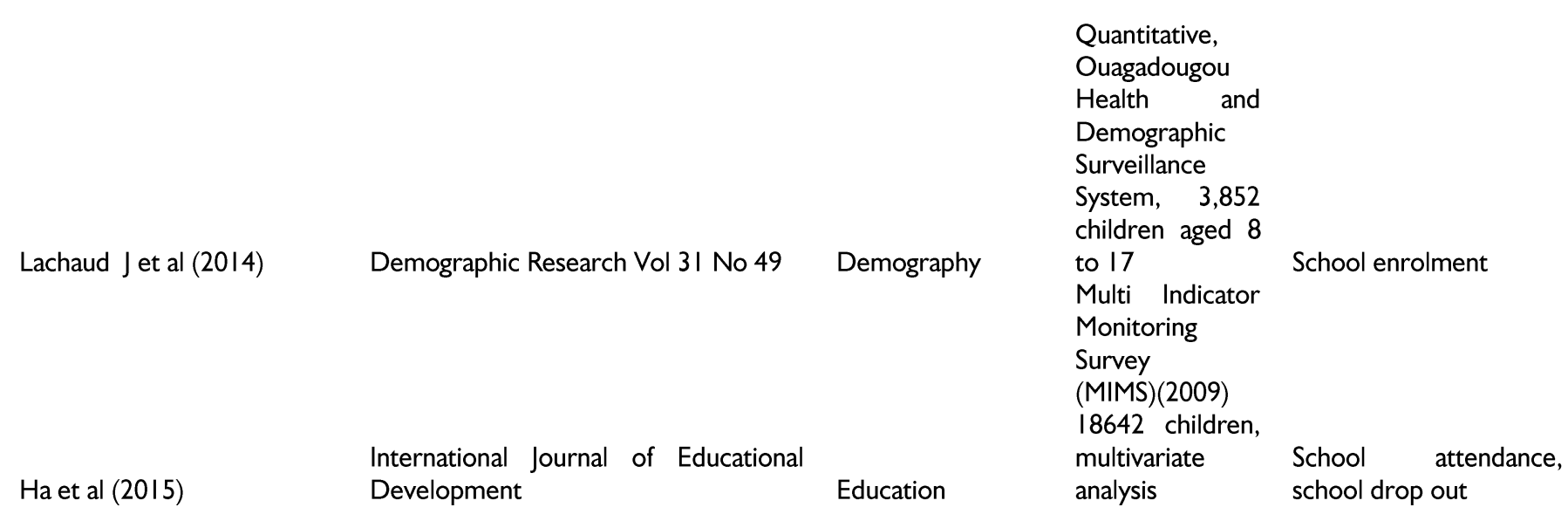

Table 13: Descriptions and findings of research addressing family change and child survival

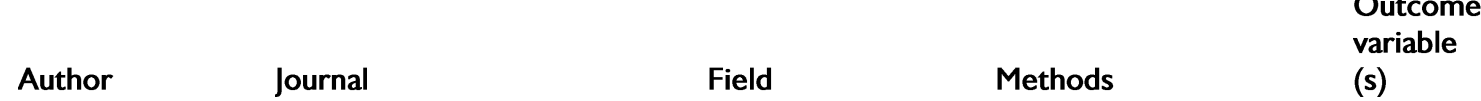

\begin{tabular}{|c|c|c|c|c|}
\hline $\begin{array}{l}\text { Omariba D \& } \\
\text { Boyle M (2007) }\end{array}$ & $\begin{array}{l}\text { Journal of Marriage and Family } \\
\text { Vol } 69\end{array}$ & Demography & $\begin{array}{l}\text { Quantitative, } \\
\text { Demographic and Health } \\
\text { Survey data from } \\
22 \text { sub-Saharan African, } \\
\text { multilevel logistic } \\
\text { regression }\end{array}$ & $\begin{array}{l}\text { Child } \\
\text { mortality }\end{array}$ \\
\hline
\end{tabular}
Vol 69

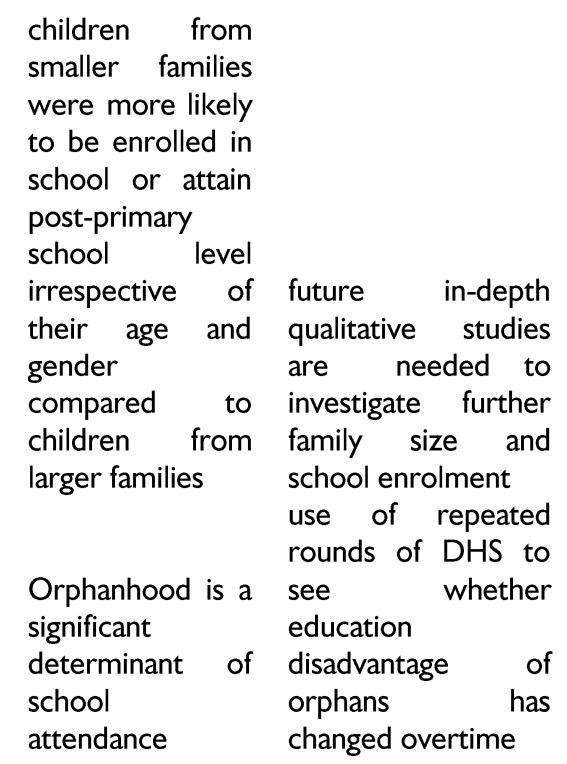

Theory

The male coercion mothers in monogamous unions model,

Female choice model

\section{Findings}

Gaps

$\begin{array}{ll}\text { children of mothers in } & \begin{array}{l}\text { research analysing } \\ \text { longitudinal data to }\end{array} \\ \text { polygynous marriages were } & \text { compare } \\ \text { more likely to die than those of } & \text { the health of children } \\ \text { mothers in monogamous unions } & \begin{array}{l}\text { before and after a family } \\ \text { becomes } \\ \text { polygynous }\end{array}\end{array}$




\section{Clark \\ S \&}

Hamplova

(2013)

Demography (2013) 50:15211549

Demography

Quantitative, DHS data

from II countries in sub-

Saharan Africa, surviva

\section{Child}

\section{mortality}

Quantitative Migration and Urban Integration Survey of Burkina Faso 17,399 children, survival Child analysis Kaplan-Meier mortality

Thiombiano B et Demographic Research Vol 29 No 29

Demography \&piecewise exponential models

Starting school

Quantitative 2008

Nigeria Demographic and Health Survey, 33 385 women

reproductive age, multi- Under-5

Izugbara C South African Journal of Child Health Vol 8 No I

\section{Demography}

children of single mothers status overtime, future especially post marital single studies

mothers were more likely to should include

die compared to children of indicators of support married mothers

future studies should examine whether there is a difference between married parents and children of divorced parents cohabiting couples in experience higher estimated terms of child mortality under 5 mortality risks and

there is a need for more in-depth studies number of children ever born into household-level in a household was a significant factors determinant of child mortality under-5 mortality 
Table 14: Descriptions and findings of research addressing family and risky sexual behaviour

Author

Journal

Field

Defo B \& Dimbuene Z African Journal of Reproductive $(2012)$ Health Vol 16 No 12

Demography

Methods

Quantitative,

Cameroon Family and

Health

Survey 2002, I,815

adolescents and young

adults of both sexes,

aged

12-24 years, survival Timing

analysis

\section{Outcome}

variable $(s)$

,

Timing

sexual debut
Theory Findings

further research is family changes that needed to examine the $\begin{array}{lll}\text { Socialization during } & \text { gender differences when } \\ \text { theory, Social childhood and adolescence changes in family }\end{array}$ theory, Social child have negative effects structure occurred during
control theory, stress on the timing of sexual the theory debut. life course

more research comparing risk y sexual behaviour among orphaned and non- orphaned youth in urban or rural areas is needed. A longitudinal study to forty-one percent of examine the impact of respondents reported parental illness or death sexual onset before age 15 , on sexual behaviour is condom use was low $13 \%$ also necessary

Age at sexual debut, number of sexual

Quantitative , |30| partners, undergraduate inconsistent students at a Nigerian condom use, University, binary non-regular

Odimegwu C \& Adedini S African Journal of Reproductive (2013)
Health Vol 17 No 4
12-24, binary loged experience

regression $\quad$ condom use future studies should explore further understanding of the relationship between

students from single parent family characteristics, homes showed lower poverty rating and risky likelihood of having sexual behaviour among multiple sexual partners. students 
Qualitative,

Community and systematic review was

Frantz J et al (20I5)

The Open Family Studies Journal Vol I5 No I conducted between Health Risk

2000 and 2014
Health Risk
Behaviours

there is lack of methodologically rigorous research that can provide empirical evidence and insight regarding the There was a relationship relationship between between family structure family

and engagement in risky structure and engagement sexual behaviour

in health risk behaviour

\section{Table 15: Descriptions and findings of research addressing family change, poverty and resource allocation}

\section{Author}

Journal

Journal of Biosocial Science Vol 38 No

Katapa R (2006)

Goebel et al $(2010)$

Health \&Place Vol 16
Field

Sociology

households in

Geography and Msunduzi

Environmental Municipality

studies

Quantitative,

Demographic and

Health Survey

\section{Outcome}

regression Poverty variable (s)

Theory

indings

female-headed

households were poorer

than male headed

households

Female employment and lower educational attainment

than male headed households

Poverty
Qualitative, $\quad 100$ Experiences of families with

fathers Experience

Kimani E \& Kombo K (20I0)
The African Symposium Vol 10 No 2 Gender studies
Structural families with functionalism absent fathers theory families with absent fathers faced provision crisis, women without male partner were denied access control of family assets and resources such as family land

\section{Gaps}

variables such as marita status of members of the household, including that of the head of household were not answered in the Tanzania 2000 DHS so studies could consider these variables

more local-level studies that disaggregate data at least to the ward level and by household types are needed 
African Population Studies Vol. 3I, No. I,(Supp. 2), 2017

Muleta A \& Deressa D (2014) Research Vol 3 No I
Science, Technology and Arts

Quantitative

Ethiopian Rural

Household Survey

from 1999-2009,

logistic regression Poverty

\section{Quantitative,}

Ouagadougou

Health

and

Demographic

Surveillance System,

3,852 children aged School

Lachaud J et al

Demographic Research Vol 3 I No 49 Demography
8 to 17

enrolment
$35.3 \%$ of the sampled

female headed

households in rural the study did not examine

Ethiopia were poor, the marital status of

female headed female headed households

households poorer than as it has an impact on their

male headed households wealth status

children from smaller families were more likely to be enrolled in schoo

or attain post-primary future in-depth qualitative school level irrespective studies are needed to of their age and gender investigate further on compared to children family size and school from larger families

Table 16: Descriptions and findings of research addressing policies

$\begin{array}{lllll}\text { Author } & \text { Journal } & \text { Field of study } & \text { Methods } & \begin{array}{c}\text { Outcome } \\ \text { variable(s) }\end{array} \\ & & & \\ & & & \\ \text { Patel L \& Hochfeld T (2011) Vol } 19 & \text { Gender \& Development } & \begin{array}{l}\text { Social } \\ \text { Development } 2\end{array} & \begin{array}{l}\text { Quantitative, 344 women, } \\ \text { primary data collection }\end{array} & \begin{array}{c}\text { Gender } \\ \text { relations }\end{array}\end{array}$

\section{Findings}

30 per cent said the

fathers of their

children no longer

provide support now

that they get the child support grant

\section{Gaps}

conducting the field work on week-days excluded those with regular

employment away from home 
African Population Studies Vol. 31, No. I,(Supp. 2), 2017

Jordan N, Patel L, Hochfeld T (2014)
Mixed Methods, a sub sample of 37 mothers out of household survey of of household survey of interviews were

conducted with 20 young mothers between the ages of 16 and 25 years

\section{Early motherhood}

Mixed method, 25 semistructured interviews, 5

focus group discussions, Perceptions on the 72 questionnaires, use of child primary data collection

Qualitative, 25 in-depth interviews with Old Age Grant recipients, primary data

Mediterranean Journal of

Tangwe $\mathrm{P}(2013)$
Social Sciences Vol 4 No 13 Social Work support grant

some of the young

women

were

encouraged to fall

pregnant so that their

families could access

the child grant $25 \%$ of

the women reported

that their children's

fathers were no

longer giving them

financial support since

they started receiving

the grant

the study was

$63 \%$ of participants in

the quantitative study

saw a direct link

between

the the

introduction of the contradictory

grant and teenage nature of responses

pregnancy, $\quad 90 \%$ suggest that further

reported that the quantitative and

grant was abused, qualitative -studies

uses such as into the actual use

empowering women, and possible abuse educating children of the CSG by its and starting small recipients, as well

businesses were as the reasons discussed in the focus behind this are groups needed

old age grant helps

with poverty

reduction in the more advanced

Poverty

households

in Social Exchange

intergenerationa

more advanced
national research studies are needed 